Portland State University

PDXScholar

1992

\title{
Effects of parents' health attitudes and beliefs on children's preventive care utilization
}

Weiming $\mathrm{Hu}$

Portland State University

Follow this and additional works at: https://pdxscholar.library.pdx.edu/open_access_etds

Part of the Sociology Commons

Let us know how access to this document benefits you.

\section{Recommended Citation}

Hu, Weiming, "Effects of parents' health attitudes and beliefs on children's preventive care utilization" (1992). Dissertations and Theses. Paper 4315.

https://doi.org/10.15760/etd.6199

This Thesis is brought to you for free and open access. It has been accepted for inclusion in Dissertations and Theses by an authorized administrator of PDXScholar. Please contact us if we can make this document more accessible: pdxscholar@pdx.edu. 
AN ABSTRACT OF THE THESIS OF Weiming Hu for the Master of Science in Sociology presented February 17, 1992.

Title: Effects of Parents' Health Attitudes and Beliefs on Children's Preventive Care Utilization.

APPROVED BY THE MEMBERS OF THE THESIS COMMITTEE:

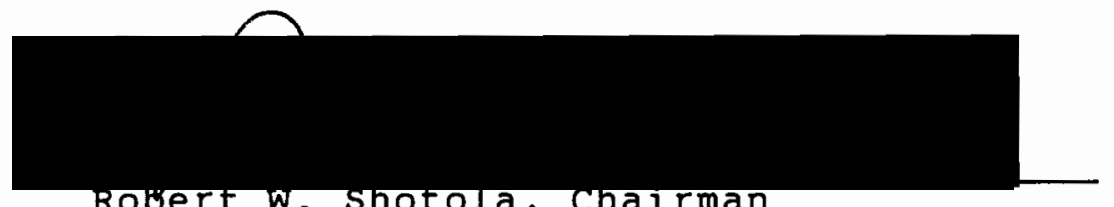

Robert w. Shotola, chairman
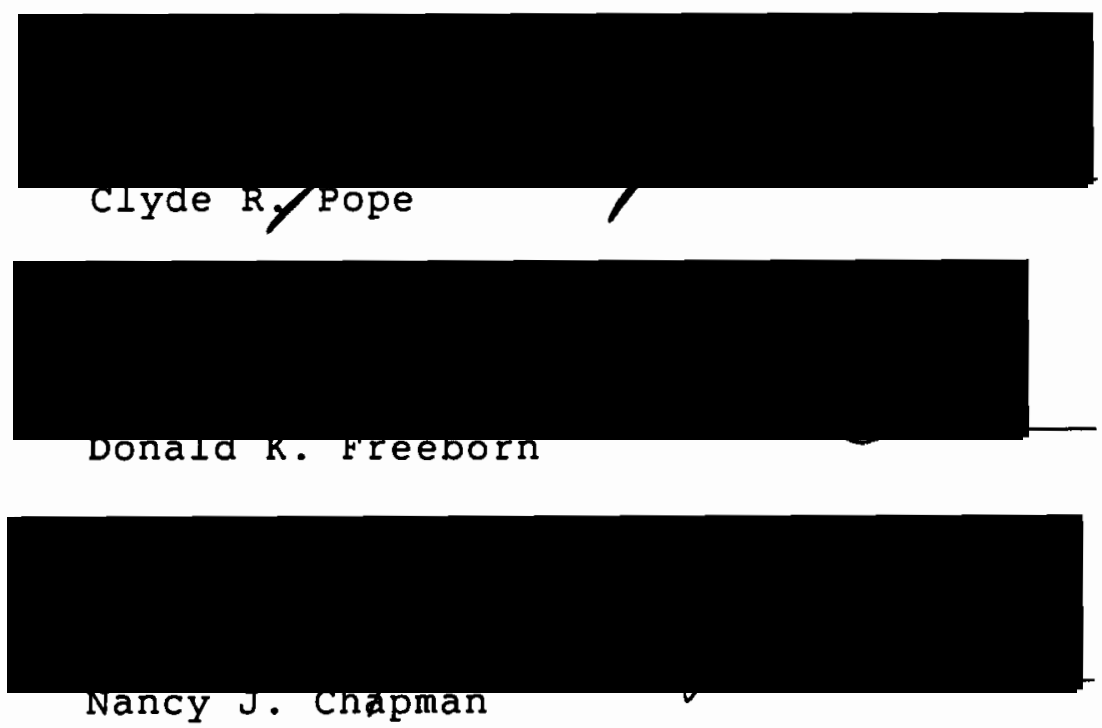

This thesis was designed to test the relationship between parents' health attitudes and beliefs and utilization of preventive health services of their children. Four measures of health attitudes and beliefs ( $H A B$ ) were examined in this study, they were: 1) Interest 
in and concern with health; 2) skepticism about physicians;

3) Tendency to consult physicians; and 4) Efficacy. Preventive care utilization included well-child care and immunization.

The setting for this study was the Northwest Region of the Kaiser Permanente Medical Care Program, a prepaid group practice HMO serving mainly the portland-Vancouver Metropolitan area. This study included 143 families. The study population was a subset of a five percent random sample of subscriber units (families) with children who were $0-3$ years old at the time when the survey was conducted in 1970-71. The data on use of children's preventive care services were derived from the computerized Outpatient Utilization system of the Center for Health Research, Kaiser Permanente Northwest Region. The data on parents' health beliefs and attitudes were derived from a household interview survey.

The findings in this study do not provide clear support for the primary hypothesis that children's preventive care visits are associated with parents' health attitudes and beliefs. Rather the results seem to favor the secondary hypothesis that mothers' health attitudes and beliefs have more influence on children's preventive care visits than fathers'. Multiple regression analyses show that more variance in preventive care visits is explained by mothers' $H A B$ indices than fathers'. 
This study tends to support the Health Locus of Control theory, since the only $\mathrm{HAB}$ index that supports the hypothesis is efficacy; mothers' efficacy is significantly associated with well-child visits and children's total number of vaccinations. 
EFFECTS OF PARENTS' HEALTH ATTITUDES AND BELIEFS ON CHILDREN'S PREVENTIVE CARE UTILIZATION

$$
\text { by }
$$

WEIMING HU

A thesis submitted in partial fulfillment of the requirements for the degree of

\author{
MASTER OF SCIENCE \\ in \\ SOCIOLOGY
}


TO THE OFEICE OF GRADUATE STUDIES:

The members of the Committee approve the thesis of Weiming Hu presented February 17, 1992.

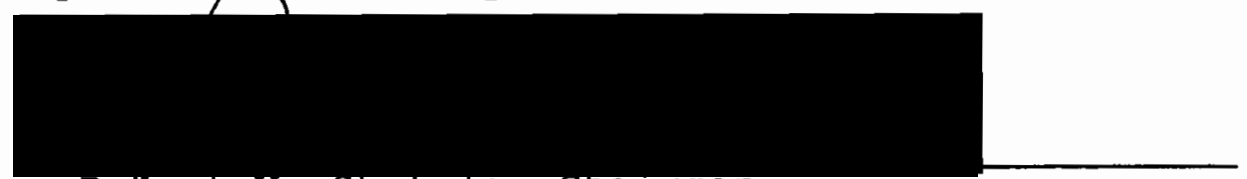

Robert w. Shotola, chairman

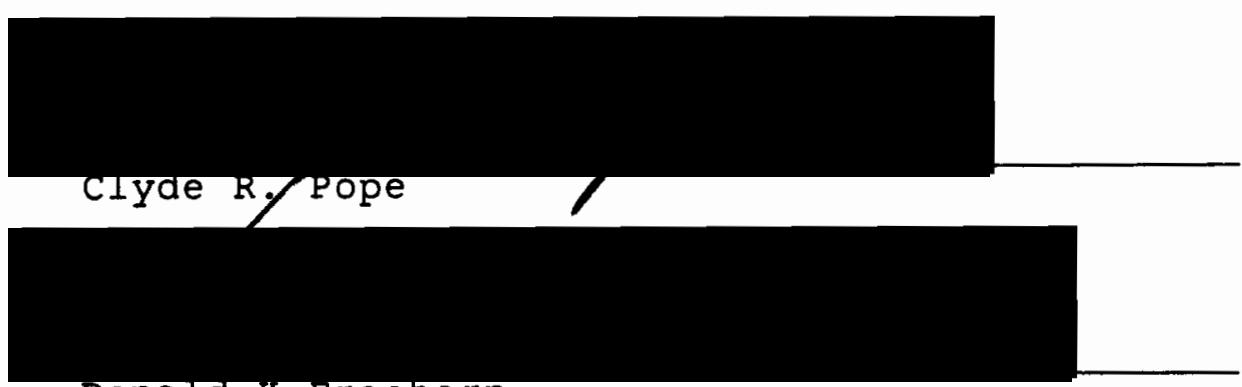

Donald K Freeborn

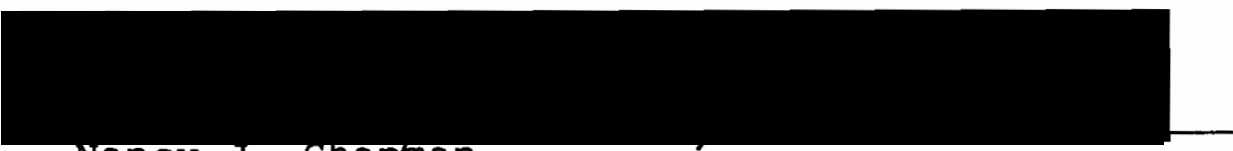

Nancy J. chapman

\section{APPROVED :}
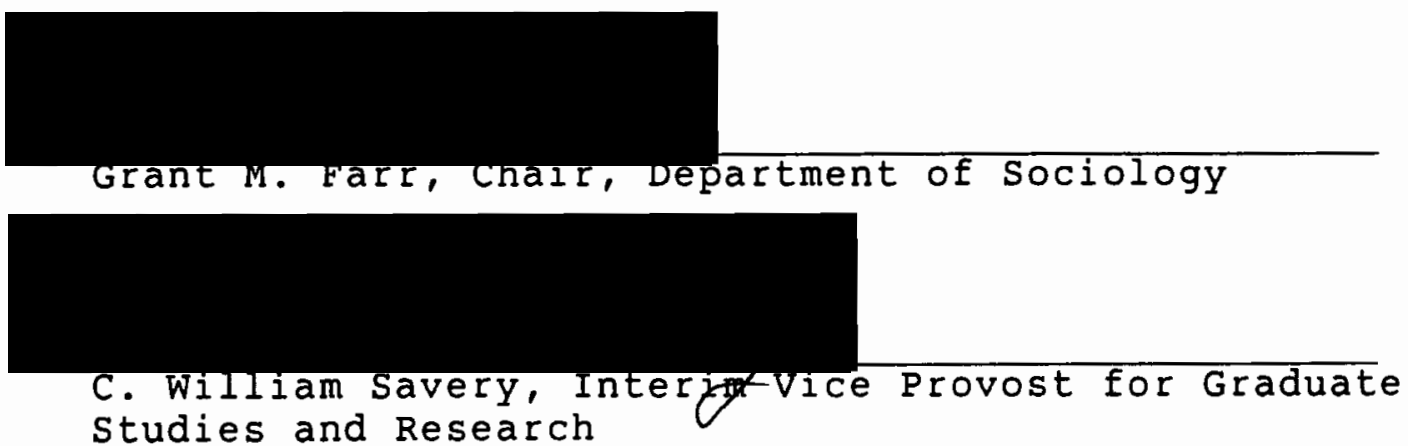


\section{ACKNOWLEDGMENTS}

On completion of this thesis, I express my gratitude to Center for Health Research (CHR), Kaiser Permanente Northwest Region, for all of the resources made available to me to do this study. I would like to thank all my colleagues at CHR for their help, time and encouragement. My appreciation especially goes to Clyde Pope and Donald Freeborn, who are also members of my thesis committee. Getting to know Clyde has been one of the most important benefits of my work on this project. Over the course of my thesis studies, both Clyde and Don have guided me toward greater understanding of the research process, and helped me in my professional development as a medical sociologist.

I want to thank Dr. Robert Shotola, chairman of my thesis committee and long time friend of mine, for spending hours patiently editing my thesis and correcting my writing. I am also grateful to Dr. Nancy Chapman, the graduate office representative, for her suggestions and comments which greatly improve the quality of my thesis.

I wish to thank all my family and friends for their encouragement, especially Jim and Rita Meiser for their love and support. Finally, I would like to thank my mother for her love and understanding. This thesis was written with her in my mind and is dedicated to her. 
TABLE OF CONTENTS

PAGE

ACKNOWLEDGMENTS

ii

LIST OF TABLES

vi

CHAPTER

I INTRODUCTION . . . . . . . . . . . . . 1

Issues and Problems........... . . 1

Literature Review . . . . . . . . . 2

Hypotheses . . . . . . . . . . . 13

II METHODOLOGY . . . . . . . . . . 18

Research setting . . . . . . . . 18

Data Sources . . . . . . . . . . 19

study Population . . . . . . . . . 20

Variable Measurement . . . . . . . . 21

Data Analysis... . . . . . . . 28

III FINDINGS . . . . . . . . . . . . 32

Characteristics of the study Population . . 32

Characteristics of Independent variables . 33

HAB and Well-child Care . . . . . . 38

HAB and Vaccinations . . . . . . . . 44 
DISCUSSION AND CONCLUSION . . . . . . . 66

Discussion of the Hypotheses . . . . . 66

Iimitations of the study . . . . . . . 71

Implications of This Research . . . . . 72

Recommendations for Future Research . . 73

REFERENCES • . • . . . . . . . . . . . . . . 75

APPENDIX . . . . . . . . . . . . . . . . . . . 80 


\section{IIST OF TABLES}

TABLE

PAGE

I Comparisons of Characteristics of Mothers and Fathers . . . . . . . . . . . . . 33

I Frequency Distribution of Mothers' and

Fathers' Interest in and Concern

with Health Index . . . . . . . . . 34

II Frequency Distribution of Mothers' and

Fathers' Skepticism about Physicians Index . 34

IV Frequency Distribution of Mothers' and

Fathers' Tendency to Consult Physician

Index . . . . . . . . . . . . . . 35

$\mathrm{V}$ Frequency Distribution of Mothers' and

Fathers' Efficacy Index . . . . . . . 36

VI Correlation between Mothers' and Fathers' HAB

Indices and sociodemographic Variables . . 37

VII Correlation between Parents' HAB Indices and

Sociodemographic Variables . . . . . . 38

VIII Frequency Distribution of Well-child

Care Visits . . . . . . . . . . 38

Ix Correlation between Mothers', Fathers', and

Parents' Characteristics and Children's

We11-child Visits 
X Multivariate Regression on Well-child visits:

Model 1 versus Model 2 . . . . . . . . . 41

XI Stepwise Regression on Well-child visits:

Model 3 . . . . . . . . . . . . 42

XII Stepwise Regression on Well-child Visits:

Model 4 . . . . . . . . . . . . . 43

XII Completion Rates of Five selected vaccines . . 44 XIV summary of $x^{2}$ Tests of the cross-tabulation

between Health Concern (HC) and Each Vaccine 45 XV Summary of $\mathrm{x}^{2}$ Tests of the cross-tabulation

between Skepticism (SK) and Each Vaccine. . 46

XVI Summary of $\mathrm{x}^{2}$ Tests of the cross-tabulation between Tendency to Consult Physician (TCP) and Each Vaccine . . . . . . . . . 47

XVII Summary of $x^{2}$ Tests of the cross-tabulation between Efficacy (EFF) and Each Vaccine . 48 XVIII Stepwise Discriminant Analysis on Completion of Polio: Model A . . . . . . . . . 4 49

XIX Stepwise Discriminant Analysis on Completion of Polio: Model B ............ 50

$\mathrm{XX}$ Stepwise Discriminant Analysis on Completion of DPT: Model A . . . . . . . . . 51

XXI Stepwise Discriminant Analysis on Completion of DPT: Model B . . . . . . . . . . 51

XXII Stepwise Discriminant Analysis on Completion of Measles: Model A . . . . . . . . 52 
XXIII Stepwise Discriminant Analysis on Completion of Measles: Model B . . . . . . . . 52

XXIV Stepwise Discriminant Analysis on Completion of Smallpox: Model A . . . . . . . 53

XXV Stepwise Discriminant Analysis on Completion of Smallpox: Model B .......... 53

XXVI Stepwise Discriminant Analysis on Completion of Mumps: Model A . . . . . . . .

XXVII Stepwise Discriminant Analysis on Completion of Mumps: Model B . . . . . . . . .

XXVIII Frequency Distribution of Total Number of Vaccinations

XXIX Correlation between Mothers', Fathers', and Parents' Characteristics and Total Number of Vaccinations... . . . . . . . 56

XXX Multivariate Regression on Total Number of Vaccinations: Model 1 versus Model 2 . . 57 XXXI Stepwise Regression on Total Number Vaccinations: Model 3 . . . . . . . . 58 XXXII Stepwise Regression on Total Number Vaccinations: Model 4 . . . . . . 58 XXXIII Frequency Distribution of vaccination Completion scale . . . . . . . . 59 XXXIV Correlation Between Mothers', Fathers', and Parents' HAB Indices and Completion scale. 60 
XXXV Multivariate Regression on Completion Scale:

Model 1 versus Model 2 . . . . . . . 62

XXXVI Stepwise Regression on Completion

Scale: Model 3 . . . . . . . . 63

XXXVII Stepwise Regression on Completion

Scale: Model 4 . . . . . . . . . 63

XXXVIII Stepwise Discriminant Analysis on Completion

Scale: Model A ............ 64

XXXIX Stepwise Discriminant Analysis on Completion

Scale: Model B ............ 65 
CHAPTER I

INTRODUCTION

ISSUES AND PROBLEMS

My thesis is concerned with testing the relationship between parents' health attitudes and beliefs and utilization of preventive health services of their children. The decline in vaccination rates in the United states has drawn public attention in recent years. According to a recent survey by the Centers for Disease Control ( $C D C)$, fewer than half of all 2-year-olds in nine large cities are fully immunized [spears, 1991]. This thesis will try to offer some social psychological insights with regard to factors influencing vaccination.

Research indicates that there is a significant relationship between attitudes and beliefs that one holds, and behavior that one performs. Many studies in the literature have examined the relationship between health attitudes and beliefs and utilization of medical service. Variables commonly included in these studies are age, sex, education, family income, and family's social class. Relatively few studies are related to preventive care utilization, and very few studies have examined utilization of preventive care of their children. 
In general, there are two distinct opinions as to how wellness should be reached. One set of opinions is oriented toward curative medicine. A second set of opinions favors preventive medicine. How do different health attitudes and beliefs affect children's utilization of preventive care? This study examined four measures of health attitudes and beliefs: 1) Interest in and concern with health; 2) Skepticism about physicians; 3 ) Tendency to consult physicians; and 4) Efficacy. (The conceptualization and index construction will be discussed below.) I have explored how each measure relates to children's utilization of preventive medical care. As we know that different people have different opinions toward achieving health for their children, the examination of these measures will provide information about how attitudes and beliefs influence parents' behavior in getting immunization for their children.

\section{LITERATURE REVIEW}

\section{General Perspectives}

The concept of attitude has played a major role in the field of social psychology. Early on, social scientists viewed attitudes as behavioral dispositions. They assumed that attitudes could be used to explain human behavior. Contemporary social scientists view attitudes as complex systems comprising persons' beliefs, their feelings 
toward the object, and their action tendencies with respect to the object. Most social psychologists favor the view that the attitude consists of three components: cognitive, affective, and behavioral.

The relationship between attitude and behavior has been very controversial. Some studies have shown attitude-behavior inconsistency. The classic example is the study reported by Richard Lapiere in 1934 [Lapiere, 1934]. The study revealed the inconsistency between hotel managers' expressed unwillingness to accommodate a Chinese couple and their actual behavior when confronting the couple in the real situation. Other studies have shown attitude-behavior consistency [Green, 1972; Fendrich, 1967; Vroom, 1964; Mann, 1959; Wicker \& Pomazal, 1971], but there exists a distinction between attitude as a cause of behavior, and attitude merely as a correlate of behavior.

There are two major theories in socio-psychological literature seeking to explain the relationship among beliefs, attitudes, and behavior: the theory of reasoned action and cognitive consistency theory (cognitive dissonance theory).

The Theory of Reasoned Action. The theory of reasoned action was formulated by Ajzen and Fishbein [1980]. There are four variables in their theoretical framework. They are beliefs, attitudes, intentions, and behavior. According to the theory of reasoned action 
[Ajzen and Fishbein, 1980], behavior is ultimately determined by beliefs, but there is not a direct link between beliefs and behavior. Beliefs influence attitudes and subjective norms; these two factors, in turn, determine intentions; and intentions influence behavior.

Thus, behavioral change is ultimately the outcome of changes in beliefs. "In order to influence behavior, we have to expose people to information which will produce changes in their beliefs" [Ajzen and Fishbein, 1980]. In addressing the repeated finding of a low relationship between attitudes and behavior, Ajzen and Fishbein argue that it occurs because most measures of attitudes only assess the affective component of the attitude. In order to obtain a complete measure of attitude, researchers should have taken into account the cognitive and behavioral components of the attitude. The Theory of Cognitive Dissonance. Another perspective that has often been used to explain the relationship among belief, attitude, and behavior is Leon Festinger's theory of cognitive dissonance [Festinger, 1957]. It assumes that individuals strive toward consistency among their beliefs, attitudes, and behaviors. Cognitive elements can be in one of three kinds of relationships: consonant, dissonant, and irrelevant. Festinger's theory deals with the consistencies and inconsistencies between an individual's perceptions of his 
own behavior and his beliefs or attitudes. The theory postulates that if an individual is induced to engage in behavior that is inconsistent with his beliefs or attitudes, he will experience the discomfort of dissonance (psychological inconsistency), and be motivated to reduce or avoid the dissonance. Festinger assumes that the inconsistencies exist within the individual's own cognitive system.

One of the most useful ideas that dissonance theory has pointed out is that the relationship between attitudes and behavior can change. Changes in attitudes should be followed by corresponding changes in behavior. A person can change dissonant cognitive elements to consonant elements by changing his behavior, if that behavior contains the dissonant elements.

To summarize, the theory of reasoned action seemingly assumes that there is a causal relationship between belief, attitude, and behavior. It argues that behavior is determined by attitudes. The attitude-behavior inconsistency is mostly due to the methodological problem in measuring attitudes. The cognitive dissonance theory postulates that individuals strive toward consistency when there exists inconsistency.

Perspectives on Health Services Utilization Behavior

There are several different approaches toward dealing with the determinants of health services 
utilization. Wolinsky [1988] has summarized seven general types of health services utilization models: demographic, social structural, social psychological, family resource, community resource, organizational, and health systems models. These models are not necessarily mutually exclusive. Some of them are closely related. I will not detail each of these models. Instead, I will examine the following three theories: Mechanic's general theory of help seeking, Suchman's stages of illness (medical care model), and Andersen's behavioral model.

David Mechanic [1968] took a social psychological approach to the study of illness behavior. He emphasized two factors in help-seeking behavior: 1) the perception or definition by the individual of the situation; and 2 ) the ability of the individual to cope with that situation.

In his ideal model of illness and medical care-seeking behavior, Suchman [1965] used five stages to analyze the patterns in the process of seeking, finding, and carrying out of medical care. He also found that medical care-seeking behavior could be explained by the structure of the group to which individuals belonged. He identified two major types of group structure, parochial and cosmopolitan. Parochial social groups have a traditional orientation toward medicine with little knowledge of disease and more skepticism toward medical care. Cosmopolitan social groups have a scientific 
orientation toward medicine and are more open to change. In his behavioral model, Andersen [1968] has identified three major categories of health services utilization determinants: predisposing characteristics, enabling characteristics, and need characteristics. Need (such as perceived threat) is the basic and direct stimulus for the use of health services when the appropriate levels of predisposing and enabling characteristics exist.

In summary, Mechanic's approach is tied to the theoretical tradition of the definition of the situation [Thomas, 1918]. A person's definition of the situation plays a major role in his medical care-seeking behavior. Like Mechanic, suchman emphasizes that individual perception of disease is the key determinant of health related behavior. Andersen emphasizes that the need (such as perceived threat of disease) is the basic determinant of health services utilization.

Perspectives on Preventive Health Behavior

People's health behavior is affected by many influences. These include culture, family, peer, mass media and other factors. As defined by Kasl and Cobb [1966], health behavior is "any activity undertaken by a person believing himself to to healthy, for the purpose of preventing disease or detecting it in an asymptomatic state." This is in contrast with illness behavior and sick-role behavior. The health behaviors include two types 
of actions. The first category of actions involves direct contact with health care professionals, such as vaccinations, check-ups and the like. The second category relates to compliance with recommendations of medical professionals (e.g. low cholesterol intake, weight loss, exercise). Noticing that a lot of behaviors are outside the medical care system, Harris and Guten defined Health Protective Behavior as: "any behavior performed by a person, regardless of his or her perceived or actual health status, in order to protect, promote, or maintain his or her health ...." [1979, p. 18] The term Preventive Health Behavior in this context will include both concepts.

There are two major models that have been used to explain preventive health behavior. They are the Health Belief Model and the Locus of Control Model.

The Health Belief Model. The Health Belief Model was originally formulated by Hochbaum, Leventhal, Kegeles, and Rosenstock in an effort to extend the use of sociopsychological variables to the explanation of preventive health behavior [Becker, 1974]. Marshall Becker [1974] has developed the 'Health Belief Model' (HBM) in an effort to understand why some people failed to take measures known to prevent disease. This approach assumes that four key factors are involved in an individual's decision to take action against a disease:
1) perceived susceptibility;
2) perceived seriousness; 
3) perceived benefits and barriers; and 4) cues to action: it is necessary for the individual's action to be cued or triggered by some external factors (mass media messages, friend's advice, etc.) [Becker, 1974].

The HBM suggests that preventive action taken by an individual to avoid a disease relates to that individual's perception that he is personally susceptible, and that by taking a particular action, susceptibility and severity of the disease would be reduced. While health beliefs can be regarded as sufficient conditions for behavior, there are also modifying factors in Becker's model. These include demographic variables, sociopsychological variables, and structural variables. These variables serve to condition both individual perceptions and the perceived benefits of preventive actions.

The HBM has been employed successfully in several studies of preventive health behavior. Leventhal and his colleagues [Leventhal et al, 1960] studied the impact of the threat of influenza on subsequent preventive action and found that those who scored relatively high on a combination of beliefs in their own susceptibility to influenza and the severity of the disease were more likely to take preventive action that those who scored low. Heinzelmann [1962] conducted a study with 284 college students who had a history of rheumatic fever and/or rheumatic heart disease. His results indicated that 
prophylaxis behavior was significantly related to:

1) beliefs concerning perceived susceptibility to a recurrent attack; 2) beliefs concerning self-defined seriousness of the person's rheumatic fever attack; and 3) beliefs and knowledge concerning various aspects of rheumatic fever.

Regeles found that the perception of susceptibility was associated with subsequent preventive dental visits, while perceptions of seriousness and benefits were not related to subsequent preventive behavior [Kegeles, 1963]. Gochman found that if children are motivated to have good health in general, their perception of vulnerability to tooth disease and the benefits of visiting the dentist would result in their intentions to seek future dental care [Gochman, 1971].

There are few data in the literature regarding the effects of parents' health attitudes and beliefs on their health behavior on behalf of their children. In particular, very little work has paid attention to fathers' health attitudes and beliefs. In his article, "Mothers" Health Beliefs and Children's Clinic Visits," Marshall Becker [Becker et al, 1977] has identified specific maternal attitudes and beliefs that will predict mothers' subsequent utilization of health services for their children. Maiman [Maiman et al, 1982] has found significant correlations between some of the mothers' 
medication-related attitudes and the number of medications and medical appliances kept at home for their children. The Locus of Control Theory. The Locus of control Theory was derived from social learning theory, which states that a person's actions are taken on the basis of the expectancy regarding the nature of the causal relationship between one's own behavior and its consequences [Rotter, 1966]. The locus of control theory hypothesizes that behavior is a function of the expectancy that a certain action will lead to a particular goal. According to the theory, internally oriented individuals (internals) believe that their decisions and actions will influence what happens to them. Externally oriented individuals (externals) believe that consequences are not contingent upon their actions. They have no control of the situation.

The notion of locus of control has been applied to the health area since Seeman and Evan's [1962] study of alienation among hospitalized tuberculosis patients. So far, studies have found that internal locus of control has been linked to health related behaviors. Dabbs and kirscht found that the relationship between the taking of flu shots and motivation to exert control was positively related, while the relationship between the taking of flu shots and expectancy of control was negatively related. They argue that the negative relationship between expectancy and 
inoculation is because expecting control can lead to a feeling of invulnerability and a resulting lack of concern [Dabbs \& Kirscht, 1971].

James examined the effect of internal and external control upon changes in smoking behavior. His study was conducted one week after the release of the government report on smoking. His findings include: 1) both male and female smokers are significantly more externally controlled than nonsmokers; 2) smokers who were convinced by the evidence in the report had lower external control scores than those not convinced; and 3 ) among males, those who stopped smoking following the report were more internally oriented than those who continued smoking [James et al, $1965]$.

Balch and Ross [1975] studied the relationship between locus of control and completion and success in a self-control weight reduction program. Their results indicated significant correlations between the internal control score (Rotter's I-E scale) and both completion and success in the program.

Researchers have begun to look at the determinants of health locus of control (HLC) beliefs. Rotter argued that HLC beliefs develop from specific experiences and past reinforcement history. Studies have shown that internal locus of control is associated with nurturent and accepting parenting and with consistent discipline [Lau, 1982]. 
Middle-class children have consistently been found to be more internal that lower-class children [Lefcourt, 1976 and Phares, 1976]. Tolar [1978] has found that women who had many experiences with illness and accidents were more external in their beliefs. This relationship did not hold up for males.

\section{HYPOTHESES}

Based on the above discussion, the general hypothesis for this study is that children's preventive care visits are associated with parents' health attitudes and beliefs.

Hypothesis I: Children's preventive care visits are positively correlated with parents' interest in and concern with health.

According to Ajzen and Fishbein, behavioral change is ultimately the outcome of changes in beliefs [Ajzen \& Fishbein, 1980]. Dissonance theory assumes that people will tend to motivate themselves to reduce or avoid the dissonance when there are inconsistencies between behavior and beliefs or attitudes. People who think about their health and read the health articles in newspapers or magazines will be more likely to have chances to expose themselves to information, which can produce changes in their attitude and behavior. 
The Health Belief Model suggests that preventive action relates to individual's perception of susceptibility to disease and severity of disease. Human beings are rational. With interest in health and access to the right information, people will understand that susceptibility and severity of the disease would be reduced by taking a action. They will choose preventive actions in which the perceived benefits outweigh the perceived barriers.

Hypothesis II: Children's preventive care visits are negatively correlated with parents' skepticism about physicians.

Hypothesis III: Children's preventive care visits are positively correlated with parents' tendency to consult the physician.

\section{Suchman [1965] identified two types of group}

structure (parochial and cosmopolitan) to explain medical care-seeking behavior. He hypothesized that parochial groups would have a "popular" orientation toward medicine, with little health knowledge, and would be more skeptical of medical care. Cosmopolitan groups are expected to have a scientific orientation toward medicine, with more health knowledge. In seeking health care, individuals from parochial groups would place their faith in the lay referral system. In contrast, individuals from cosmopolitan groups are likely to seek professional help. Thus, parents who have low skepticism will be more likely to use health services themselves, and more likely to take 
their children to get preventive care. Also, parents who tend to consult the physician themselves are more likely to bring their children in for preventive care.

Hypothesis IV: Children's preventive care visits are positively correlated with the degree of parents' perceived efficacy.

Efficacy refers to powerfulness, planfulness, and control. Powerfulness can be defined as high expectancies for control of events; planfulness relates to the tendency to make and achieve plans with regard to future; control is concerned with the ability to bring about desired goal. Efficacy is also theoretically related to the concepts of anomie and external locus of control (the psychologist's version of powerlessness). Durkheim developed the term anomie to depict the situation where norms of society are unclear or no longer applicable to current conditions. He argued that the state of anomie was a major cause of suicide. Bandura [1977] has developed the term "self-efficacy." According to his self-efficacy theory, behaviors and courses of action are determined largely by cognitive components: outcome value, efficacy expectancy, and outcome expectancy. Locus of control is more similar to an outcome expectancy than to an efficacy expectancy because locus of control is concerned with beliefs about the outcome of one's behavior rather than with beliefs about one's ability to perform certain behaviors. 
Seeman and Evans [1962] found that powerlessness is related to tuberculosis patients' lack of knowledge concerning their illness. O'Leary [1985] reported that self-efficacy was a better predictor of relapse in smoking cessation than health locus of control.

Several studies have shown that self-efficacy measures have been related to the treatment success for smoking and obesity. Self-efficacy scales have proven useful in predicting successful completion of a treatment program [Myerson et al, 1980], post-treatment relapse [Diclemente, 1981], and smoking rates following treatment [Coletti et al, 1984]. Weinberg and his colleagues [Weinberg et al, 1984] investigated the effects of self-efficacy on weight loss. They found that the high self-efficacy group lost more weight than the low groups. They also found that locus of control was predictive of weight loss, with internals tending to lose more weight than externals.

People tend to engage in behaviors they believe they can do and to pursue those actions that will lead to the desired goals. Based on the discussion above, I think that parents who have high sense of efficacy are more likely to bring their children in for preventive medical care.

Secondary Hypothesis: The secondary hypothesis for this study is: Mothers' health attitudes and beliefs have more influence on children's preventive care visits than fathers. 
Men and women have different tasks and spheres of activities. Traditionally, women are the centers of the home and family. They have been the gatekeepers of family health. The gender stereotype is that women are expected to have warmth, compassion, and caring. So, mothers are the caretakers of children. They will have more influence regarding their children's preventive care visits than fathers. 
CHAPTER II

METHODOLOGY

RESEARCH SETTING

The setting for this study was the Northwest Region, Kaiser Permanente (KP) Medical Care Program, a prepaid group practice HMO serving the Portland-vancouver metropolitan area and in salem, oregon, and Longview, Washington. Established in 1943, the Medical Care Program currently enrolis about 374,000 members, or 17 percent of the area population. The demographic and socioeconomic characteristics of KP members correspond very closely to those of the population of the area [Greenlick et al, $1988]$

The medical group of Raiser Permanente is financially dependent upon the Health Plan which collects premiums from its members or their employers. In return, it renders all the medical services required by members, including preventive medical care at no extra cost. So, the financial barrier is not an issue for members in seeking well-child care and vaccinations. Health plan members are expected to choose physicians (internist, pediatrician, etc.) from the medical group as their regular 
doctors. Members may use any of the facilities located in the communities throughout the Northwest Region.

\section{DATA SOURCES}

The data on use of health services were derived from the outpatient Utilization system (OPUS) of the Center for Health Research (CHR), Kaiser Permanente Northwest Region. The OPUS, a computerized system, was designed and developed to record all medical care contacts of a five percent random sample of all Kaiser permanente subscriber units. The Kaiser Medical Care plan uses a single, centralized medical record for each member. The outpatient chart contains information for all medical care contacts an individual has with the program. Data coded for each contact includes time, place, and procedures rendered (including vaccination and well child care).

The data on the parents' health beliefs and attitudes were derived from the Household Interview survey (HIS) conducted by Pope in 1970. The study population of the HIS was selected from the five percent random sample of subscriber units (subscribers and their enrolled dependents), which was drawn from the list of families eligible for medical care service in kaiser Permanente Northwest Region on September 1, 1966 (each month thereafter, a five percent sample of all new families is added to the overall sample). The subset of the five percent sample used in this thesis was defined as all 
sampled subscriber units enrolled in the Medical Care Plan for the two full calendar years 1969 and 1970 . Of the 1659 subscriber units included in the subset, 1529 units had been interviewed with a response rate of $92 \%$. Respondents were the 2502 adult members of the families. Husband and wives were interviewed separately and simultaneously by two interviewers. They provided information about both themselves and the family as a whole.

\section{STUDY POPULATION}

This study looked at children who were $0-3$ years old at the time when the survey was conducted, and were covered by the medical care plan for the entire four-year period. For multiple enrollment members, if the gap between two enrollments was less than 62 days, these two enrollments were regarded as a single enrollment. For the family with more than one child qualifying for this study, I arbitrarily selected the first qualified child. The selection is only a simple way to counteract the influence of the birth-order. This study included 143 children, out of which 139 have both parents; the remaining four children have only mother or father. 


\section{VARIABLE MEASUREMENT}

Dependent Variables

The dependent variables for this study are:

1) well-child visits; 2) children's vaccination visits. Children's service utilization was traced either prospectively or retrospectively to obtain children's complete five-year records. That is to say: if a child was four years old at the time of the survey, his five-year service records would be obtained retrospectively; if a child was zero-year old, his records would be obtained prospectively; if a child was one, two, or three years old; his records would be obtained both retrospectively and prospectively.

Well-child visits were measured by the number of separate visits. For vaccination visits, I picked out the following five vaccines: DPT (diphtheria, pertussis, and tetanus), polio, measles, smallpox, and mumps. Different measures were used, including: 1) the completion of each vaccine; 2 ) The total number of vaccinations for five selected vaccines; and 3 ) the completion of these five vaccines. Different vaccines have different recommended shot series. For DPT and polio, children should have completed four separate doses for each vaccine by age 18 months. For measles and mumps, children should have completed one dose for each vaccine at age 15 months old. 
There will be some correlation between these variables because the well-child visits were usually the times when children received immunization shots.

\section{Independent Variables}

The measurement of the Health Attitudes and Beliefs was derived from constructing indices by combining items with similar face meaning in the questionnaire. Four separate measures were used to assess health attitudes and beliefs. Some of these indices are revised versions of Hibbard's indices for the same data [Hibbard, 1985]. Each of these indices is a simple summated rating scale. The description of the construction of indices will be presented below.

Interest in and Concern with Health. An index to assess the respondents' concern about health and interest in health matters. The score is created from responses to four questions. Possible scores range from 0-4. The higher the score, the greater the interest in and concern with health.

1) During the past few weeks, have you worried about your health?
1. NOT WORRIED - scored 0
2. EXTREMELY WORRIED -- scored 2
3. SOMEWHAT
- scored 1

2) would you say you think about health a great deal, fairly often, or only occasionally? 


$\begin{array}{ll}\text { 1. A GREAT DEAL } & -- \text { scored } 3 \\ \text { 2. FAIRLY OFTEN } & -- \text { scored } 2 \\ \text { 3. ONLY OCCASIONALLY } & -- \text { scored } 1\end{array}$

3) Do you happen to have any books in your home which you could use to look up information about medicine or illness?

$$
\begin{aligned}
& \text { 1. YES - scored } 1 \\
& \text { 2. NO -- scored } 0
\end{aligned}
$$

4) How often do you read the health columns or articles about health in newspapers or magazines?
1. OFTEN
-- scored 3
2. OCCASIONALLY
-- scored 2
3. SELDOM
-- scored 1
4. NEVER
- scored 0

Skepticism about Physicians. An index to indicate the degree to which one is skeptical about medical care and physicians. The index is constructed from five questions. Thus, possible scores range from 0 to 5 . The higher the score, the greater the skepticism.

1) If you go to two doctors, you will probably get two opposite kinds of advice.

$$
\begin{array}{ll}
\text { 1. AGREE } & -- \text { scored } 1 \\
\text { 2. DISAGREE } & \text {--scored } 0
\end{array}
$$

2) Doctors can't really cure diseases, they can only treat the symptoms.

$$
\begin{array}{ll}
\text { 1. AGREE } & - \text {-scored } 1 \\
\text { 2. DISAGREE } & \text {--scored } 0
\end{array}
$$


3) Doctors know a lot less about sickness than they let on.

$$
\begin{array}{ll}
\text { 1. AGREE } & \text {-scored } 1 \\
\text { 2. DISAGREE } & \text {--scored } 0
\end{array}
$$

4) When it comes to colds, headaches, and a great many other illnesses, the neighborhood druggist probably knows as much as the doctor.

$$
\begin{array}{ll}
\text { 1. AGREE } & -- \text { scored } 1 \\
\text { 2. DISAGREE } & -- \text { scored } 0
\end{array}
$$

5) Chiropractors can often give better care than ordinary physicians.

$$
\begin{array}{ll}
\text { 1. AGREE } & \text {-scored } 1 \\
\text { 2. DISAGREE } & \text {--scored } 0
\end{array}
$$

Tendency to Consult the Physician. An index to indicate a behavioral predisposition to consult a doctor when faced with a health problem. The index is constructed from a series of fourteen items (see Appendix $A$ ). In each item, the respondent is asked what one "should do" for a particular symptom. The fourteen symptoms range from the common to those more serious implications. Thus, the possible scores range from 0 to 14 .

$$
\begin{array}{ll}
\text { 1. CONSULT DOCTOR } & \text {-scored } 1 \\
\text { 2. TAKE CARE OF HIMSELF } & \text {--scored } 0 \\
\text { 3. WAIT SEE IF GO AWAY } & \text {--scored } 0 \\
\text { 4. IGNORE } & -- \text { scored } 0 \\
\text { 8. DON'T KNOW } & \text {--scored } 0
\end{array}
$$


Efficacy. An index to measure the degree to which one believes that his action will lead to desired goal, and that he has control over what is happening to him. The index is constructed from the responses to five questions. The higher the score, the greater the degree of perceived efficacy. Possible scores range from $0-5$.

1) Do you believe that what happens to you is mostly your own doing, or do you believe that you don't have much to do with the way your life is going?

$$
\begin{aligned}
& \text { 1. MOSTLY OWN DOING } \\
& \text { 2. NOT MUCH TO DO WITH IT - -scored } 1 \\
&
\end{aligned}
$$

2) Have things usually worked out in your life the way you wanted them to or have things usually gone wrong somehow?

$$
\begin{array}{ll}
\text { 1. WAY YOU WANTED } & - \text { scored } 1 \\
\text { 2. USUALLY GONE WRONG --scored } 0
\end{array}
$$

3) When things have gone wrong for you, do you feel you were usually to blame for it, or did they usually go wrong through no real fault of your own?

1. YOU TO BLAME FOR IT --scored 1

2. NO FAULT OF YOUR OWN --scored 0

4) In general, would you say you are the kind of person who usually plans things ahead, or do you usually take things as they come?

$$
\begin{array}{ll}
\text { 1. USUALLY PLANS AHEAD } & - \text { scored } 1 \\
\text { 2. TAKE THINGS AS THEY COME } & - \text { scored } 0
\end{array}
$$

5) When you make plans ahead, do you usually get to 
stick to your plans, or does something usually come up to make you change them?

$\begin{array}{ll}\text { 1. StICKS TO PLAN } & \text {-scored } 1 \\ \text { 2. HAVE TO CHANGE THEM } & \text {-scored } 0\end{array}$

Interest in and concern with health to some degree reflects four key variables in the HBM (perceived susceptibility, perceived seriousness, perceived benefits and barriers, and cue to action). People who think about health, read health columns in newspaper, and look up information about medicine in books are more likely to have better understanding of disease. Skepticism about physicians and tendency to consult physician are not directly tied to any variables in either the HBM or locus of control model. It can be argued that people who are skeptical about physicians are more likely to belong to parochial groups [Suchman, 1965]. They have little health knowledge and cannot fully understand their susceptibility and the seriousness of diseases. They are less likely to receive vaccinations and to consult physicians. The efficacy index can be seen as equivalent to internal locus of control in the locus of control model. People who believe that their action will lead to desired goals are likely to think that they have control over what is happening to them. They tend to plan things ahead of time and to achieve their plans. 
Control variables

Three control variables have been chosen for this study. They are age, education, and social class. Age is chronological age. Education is measured in seven categories, from "less than eight years" to "post college."

--"ALTOGETHER HOW MANY YEARS OF REGULAR SCHOOL DID YOU COMPLETE?"

1. Less that 8 years $(0-7)$

2 . completed 8 th grade

3. 9-11 years

4. High school grad ( 12 years)

5. Some college (13-15 years)

6. College graduate (16 years)

7. Graduate work ( 17 or more years)

Social class is a self-reported measure in which the subjects rated themselves. It consists of five categories: upper, upper middle, middle, working, and lower classes. --"WHAT SOCIAL CLASS DO YOU FEEL YOU BELONG TO NOW -WOULD YOU SAY THE UPPER CLASS, UPPER MIDDLE CLASS, MIDDLE CLASS, WORKING CLASS OR LOWER CLASS?"

1. Lower class

2. Working class

3. Middle class

4. Upper middle class

5. Upper class 
parents' Indices

Parents' combined HAB indices and sociodemographic characteristics were constructed by combining mothers' and fathers' indices for children who have both parents. They are the arithmetic means of mothers' and fathers' scores.

\section{DATA ANALYSIS}

Two general types of statistical techniques were employed in the analysis of data. They are bivariate techniques and multivariate techniques. Bivariate procedures include Pearson correlational analysis and chi-square analysis. Multivariate procedures include. multiple regression analysis, stepwise regression analysis, and stepwise discriminant analysis.

\section{Bivariate Techniques}

Chi square analysis is employed to test whether there is a relationship between two nominal or categorical variables by making comparisons between frequencies. Data from the study sample were cross-tabulated to observe the frequency distribution of the relevant variables. The chi-square statistic $\left(x^{2}\right)$ focuses on how close the obtained Erequencies are to what they are expected to be under the null hypothesis. If $x^{2}$ value is big enough to reach a statistically significant level, it can be concluded that the difference between the obtained frequencies and expected frequencies is not merely the product of sampling 
error. In another words, actual population difference exists.

The Pearson correlation coefficient $(r)$ is used to measure the degree of linear relationship between two variables that are measured on an interval level or assumed interval level scale. Pearson's $r$ ranges from -1 to +1 . A value of -1 indicates a perfect negative relationship; a value of +1 indicates a perfect positive relationship. The significance test of Pearson's $r$ is conducted to counteract the sampling error that might falsely indicate correlation between two variables in the population.

\section{Multivariate Techniques}

Multivariate regression analysis was used: 1) to compare the relative importance of independent variables in explaining variance in dependent variables; and 2) to identify which independent variables were most predictive of dependent variable. $R^{2}$, the squared multiple correlation coefficient, measures the percent of variance in the dependent variable that is accounted for by the independent variables in the regression equation. Adjusted $\mathrm{R}^{2}$ is used to adjust for the number of independent variables in the regression equation.

Stepwise regression analysis, one kind of multivariate regression analysis, is designed for the situation in which the inclusion of independent variables in the regression equation is in terms of maximizing $R^{2}$. 
There are three main methods in variable selection: forward selection, backward elimination, and stepwise selection. For this study, the stepwise selection was used. The stepwise method is a modification of the forward-selection technique. The variables entered into the equation are determined, step-by-step, by the contribution of each specific variable to the increment of the $R^{2}$. But the variables already in the model do not necessarily stay there. They can be removed from the model if they are not significant at the selected level for staying.

Stepwise discriminant analysis is designed for the situation in which the dependent variables are categorical rather than quantitative in nature. Its procedure for inclusion of variables is similar to stepwise regression analysis. The discriminant coefficients measure the relative importance of the included independent variables in discriminating between categories of the dependent variable.

One issue that is associated with stepwise regression analysis is the selection of significance levels. Serving as a threshold, significance level determines the entry and the staying of variables in the model; if significance level is specified at a very low level, say .05, then only those variables that contribute a lot to the predictive power of the model will enter and stay in the model; if it is specified at a moderate level, then those variables that contribute some to the predictive 
power of the model can enter and stay in the model. For this study, the significance level for both entry and staying was set at .30 because of the low predictive power of the $H A B$ indices. 


\section{CHAPTER III}

\section{FINDINGS}

The results of this study will be presented in four major sections. The first section describes the sociodemographic characteristics of the study population. The second section will depict the characteristics of the independent variables and control variables. The third section will deal with the analysis of the relationships between the $\mathrm{HAB}$ indices and the well-child care visits. The last section will take up the analysis of the relationships between the HAB indices and the vaccinations.

\section{CHARACTERISTICS OF THE STUDY POPULATION}

There are 143 children included in this study, out of which 139 children have both fathers and mothers; the remaining four children have only fathers or mothers. The age ranges for fathers and mothers are 20-50 and 20-43, respectively at the time of survey. Fathers' average age is about 2.5 years older than mothers' (Table I). Table I also shows that fathers' average education is 5.1 , a bit more than 'some college education'. Mothers' average education is 4.6 , between the categories of 'high school graduate' and 'some college education'. Fathers' education is about one half-point higher than mothers'. Both 
parents' average scores of self-reported social class are between 'working class' and 'middle class'. Mothers' average score is a bit higher than fathers'.

TABLE I

COMPARISONS OF CHARACTERISTICS OF MOTHERS AND FATHERS

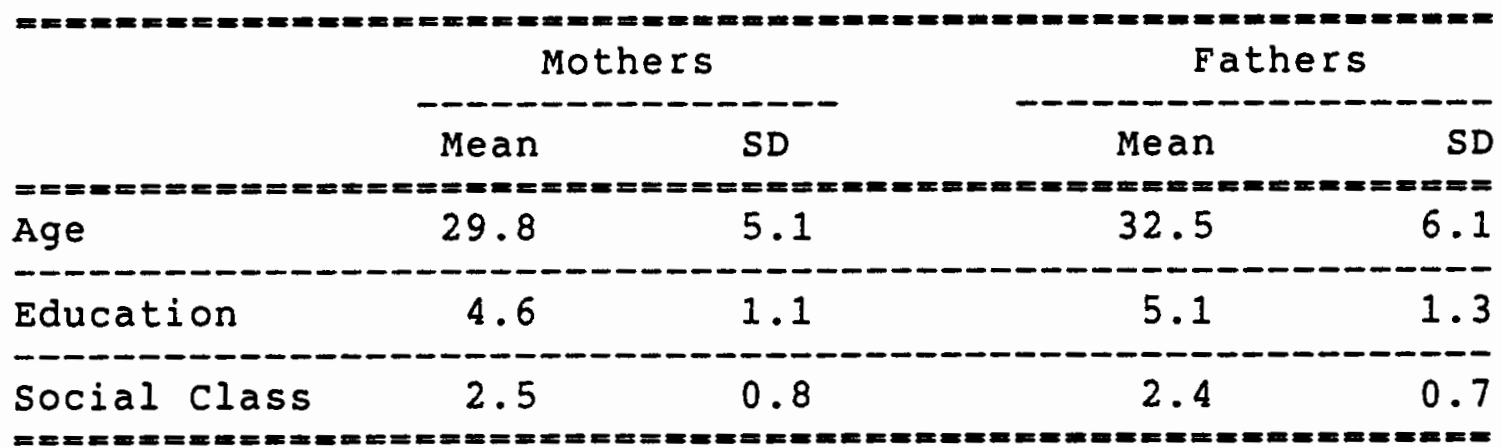

\section{CHARACTERISTICS OF INDEPENDENT VARIABLES}

Interest in and Concern with Health

The frequency distribution of the health concern score is presented in Table II. The table reveals the pattern of approximately normal distribution for both mothers and fathers. Mothers' health concern score, on the average, is .74 point higher than fathers'. The fathers' score has more variation. This finding matches Hibbard's [1985] finding that women are more interested in and concerned with health than men.

Skepticism about Physicians

Table III shows that the frequency distributions of mothers' and fathers' skepticism about physicians score are skewed to the left, with most cases clustering around the 
low score. On the average, mothers and fathers are about equally skeptical of physician.

\section{TABLE II}

FREQUENCY DISTRIBUTION OF MOTHERS' AND FATHERS'

INTEREST IN AND CONCERN WITH HEALTH INDEX

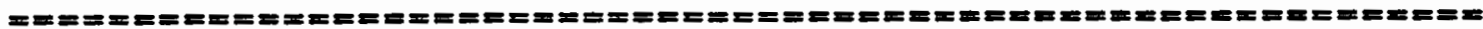
Health Interest

\begin{tabular}{lrr} 
and Concern Index & Mothers' & Fathers' \\
\hline 1 & 0 & 4 \\
2 & 3 & 15 \\
3 & 21 & 29 \\
4 & 34 Mean=4.79 & 38 Mean=4.05 \\
5 & 45 SD $=1.33$ & 30 SD $=1.42$ \\
6 & 24 & 18 \\
7 & 8 & 3 \\
8 & 4 & 0 \\
9 & 1 & 137
\end{tabular}

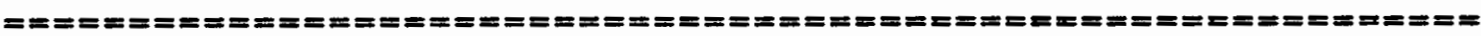

TABLE III

FREQUENCY DISTRIBUTION OF MOTHERS' AND FATHERS' SKEPTICISM ABOUT PHYSICIANS INDEX

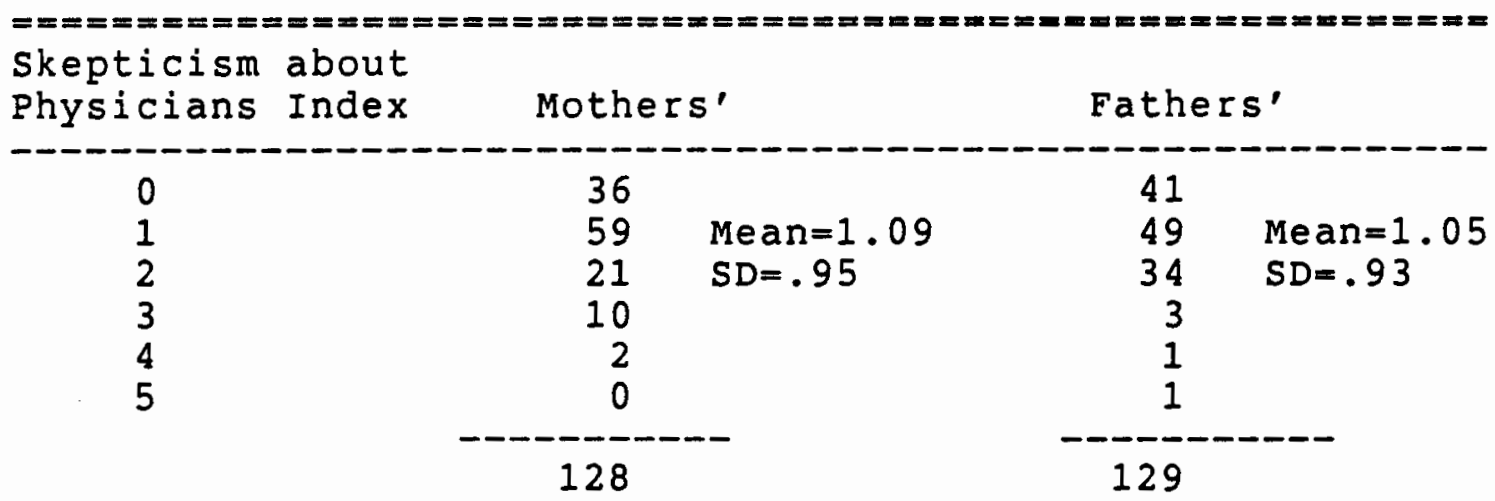


Tendency to Consult Physician

The mean scores of tendency to consult physician for mothers and fathers are 4.23 and 4.40 , respectively (Table IV). On the average, fathers are more likely to consult physician than mothers. The standard deviations show that mothers' scores have more variation. The frequency distributions of both mothers' and fathers' scores indicate closeness to normal distribution.

TABLE IV

FREQUENCY DISTRIBUTION OF MOTHERS' AND FATHERS' TENDENCY TO CONSULT PHYSICIAN INDEX

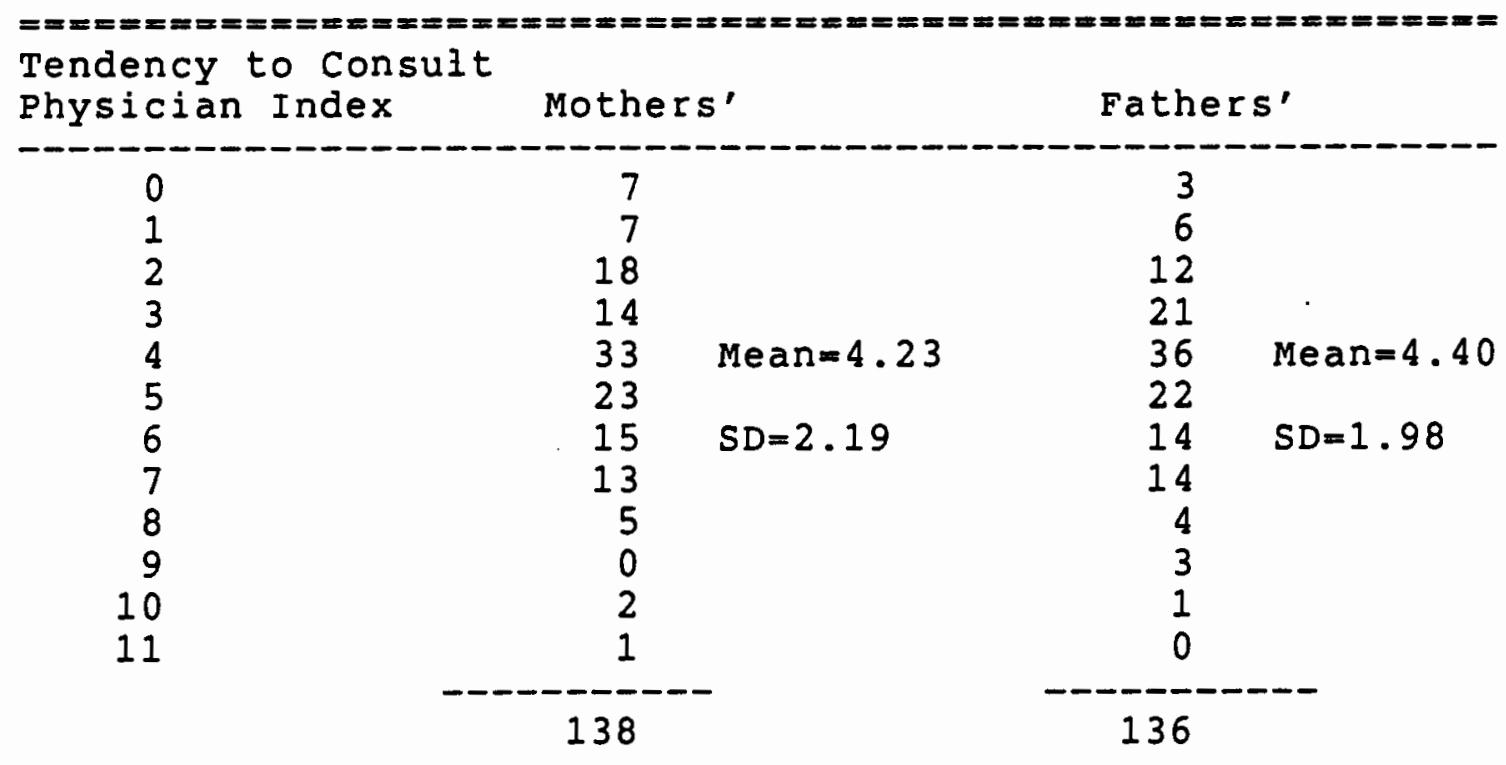

Efficacy

On the average, fathers perceived themselves as being more efficacious than mothers. The respective scores are 3.50 and 3.37 (Table V). The standard deviations of the scores indicate that mothers' scores have more 
variation than fathers'. The distributions of the scores are skewed to the right.

\section{TABLE V}

FREQUENCY DISTRIBUTION OF MOTHERS' AND FATHERS' EFFICACY INDEX

\begin{tabular}{|c|c|c|c|c|}
\hline Efficacy Index & \multicolumn{2}{|c|}{ Mothers' } & \multicolumn{2}{|c|}{ Fathers' } \\
\hline $\begin{array}{l}0 \\
1 \\
2 \\
3 \\
4 \\
5\end{array}$ & $\begin{array}{r}0 \\
3 \\
28 \\
36 \\
50 \\
17\end{array}$ & $\begin{array}{l}\text { Mean }=3.37 \\
S D=1.02\end{array}$ & $\begin{array}{r}1 \\
2 \\
15 \\
42 \\
62 \\
14\end{array}$ & $\begin{array}{l}\text { Mean }=3.50 \\
S D=.93\end{array}$ \\
\hline & 134 & & 136 & \\
\hline
\end{tabular}

Relationships Among Indices and Control Variables

Pearson correlation coefficients were computed to measure the strength of relationships among indices and fathers' and mothers' sociodemographic variables. Table VI shows that both mothers' and fathers' health concern is positively related to age. Mothers' age is significantly and negatively related to their skepticism index, with $r=-.21$. All mothers' and fathers' $\mathrm{HAB}$ indices are positively correlated with mothers' and fathers' education, but none of the relationships reaches significant level.

Both mothers' and fathers' education is positively and significantly related to fathers' and mothers' efficacy. Fathers' education and skepticism are negatively correlated, at a close-to significant level. The positive relationship between fathers' education and their health 
concern index is also close to a significant level. These findings are in correspondence with Hibbard's [1985] findings that educational level is negatively correlated with skepticism, and is positively correlated with health concern.

TABLE VI

CORRELATION BETWEEN MOTHERS' AND FATHERS' HAB INDICES AND SOCIODEMOGRAPHIC VARIABLES

\begin{tabular}{|c|c|c|c|c|c|c|}
\hline & \multicolumn{2}{|c|}{ Age } & \multicolumn{2}{|c|}{ Social Class } & \multicolumn{2}{|c|}{ Education } \\
\hline & M & $\mathbf{F}$ & $M$ & $E$ & $M$ & $\mathbf{F}$ \\
\hline $\begin{array}{l}\text { Health } \\
\text { Concern }\end{array}$ & .06 & .09 & .05 & .03 & -.02 & .16 \\
\hline Skepticism & $-.21 *$ & -.06 & .03 & .03 & -.11 & -.17 \\
\hline $\begin{array}{l}\text { Consulting } \\
\text { Physician }\end{array}$ & -.04 & .12 & .05 & .13 & -.06 & -.13 \\
\hline Efficacy & .04 & .06 & .09 & .08 & $.22 *$ & $.20 *$ \\
\hline
\end{tabular}

Parents' combined $\mathrm{HAB}$ indices and sociodemographic variables were constructed by combining mothers' and fathers measures for children who have both parents. Pearson correlation coefficients (Table VII) show a very significant relationship existing between parents' education and parents' efficacy index, and that parents' education is significantly and negatively correlated with parents' skepticism score. 
TABLE VII

CORRELATION BETWEEN PARENTS' HAB INDICES AND SOCIODEMOGRAPHIC VARIABLES

\begin{tabular}{|c|c|c|c|c|}
\hline & $\begin{array}{l}\text { Health } \\
\text { Concern }\end{array}$ & skepticism & $\begin{array}{l}\text { Consulting } \\
\text { Physician }\end{array}$ & Efficacy \\
\hline Age & .10 & -.18 & -.00 & .09 \\
\hline Social Class & .06 & .11 & .05 & .04 \\
\hline 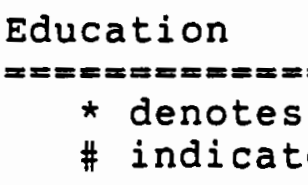 & $\begin{array}{l}.10 \\
=x=== \\
p<.05 \\
\text { es } p<.\end{array}$ & $\begin{array}{l}-.19 * \\
==x= \pm=x\end{array}$ & -.14 & $.30 \#$ \\
\hline
\end{tabular}

HAB AND WELL-CHILD CARE

Table VII gives the frequency distribution of well-child care visits. The mean number of visits is 8.0 ;

\section{TABLE VIII}

FREQUENCY DISTRIBUTION OF WELL-CHILD CARE VISITS

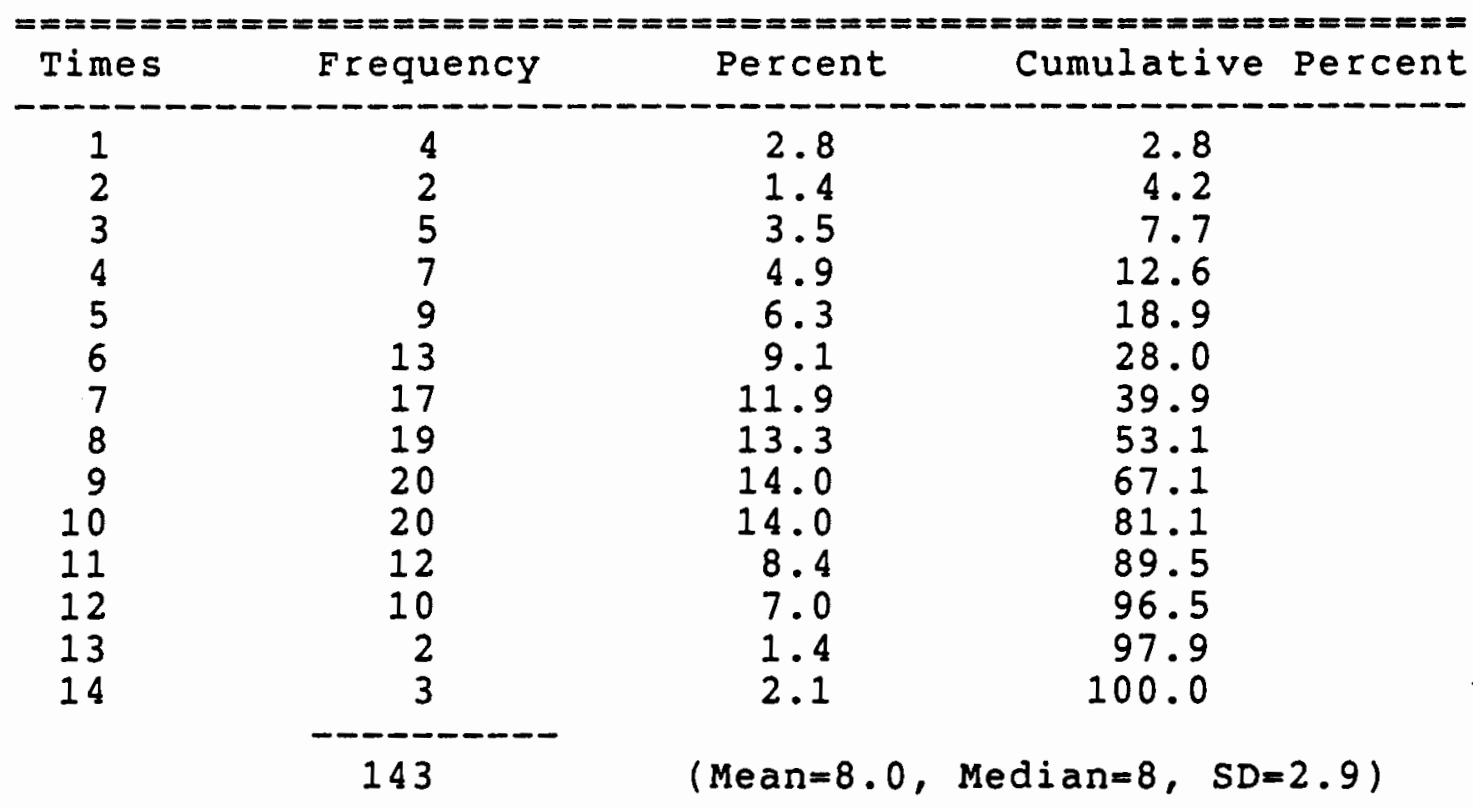


the median number is eight. It can be concluded from the distribution and statistics that the distribution of visits among these 143 children is close to a normal distribution.

\section{Pearson Correlation}

Table IX shows the relationships between number of well-child visits and the characteristics of mothers, fathers and parents. Well-child visits are very significantly associated with education of mothers, fathers and parents $(p<.01)$. Mothers' self-reported social class is significantly related to well-child visits.

\section{TABLE IX}

CORRELATION BETWEEN MOTHERS', FATHERS', AND PARENTS' CHARACTERISTICS AND CHILDREN'S WELL-CHILD VISITS

\begin{tabular}{|c|c|c|c|}
\hline & $\begin{array}{l}\text { Visits and } \\
\text { Mothers' }\end{array}$ & $\begin{array}{l}\text { Visits and } \\
\text { Fathers' }\end{array}$ & $\begin{array}{l}\text { Visits and } \\
\text { Parents' }\end{array}$ \\
\hline $\begin{array}{l}\text { Health } \\
\text { Concern }\end{array}$ & .04 & -.02 & .03 \\
\hline Skepticism & .04 & -.08 & -.03 \\
\hline $\begin{array}{l}\text { Consulting } \\
\text { Physician }\end{array}$ & -.06 & -.10 & -.10 \\
\hline Efficacy & $.18 *$ & .00 & .08 \\
\hline Education & $.37 \#$ & $.33 \#$ & $.37 \#$ \\
\hline Social Class & $.27 \#$ & -.08 & .15 \\
\hline $\begin{array}{l}\text { Age } \\
\begin{aligned}== & ======== \\
& \star \text { denotes } \\
& \# \text { indicat }\end{aligned}\end{array}$ & $\begin{array}{l}-.01 \\
====== \\
05 \\
0.01\end{array}$ & $\begin{array}{c}-.01 \\
=====\end{array}$ & $=\begin{array}{c}-.00 \\
=x==x=\end{array}$ \\
\hline
\end{tabular}


Mothers' efficacy is significantly related to number of children's well-child visits $(r=.18, p=.04)$. Within social class categories, the same relationship holds up for low social class mothers $(r=.27, p=.02)$, but not among high social class mothers $(r=.02, p=.90)$. Within educational categories, mothers' efficacy is more significantly positively related to well-child visits among less educated mothers $(r=.32, p=.00)$, but is negative for more educated mothers $(\mathrm{r}=-.30, \mathrm{p}=.04)$; mothers' skepticism about physicians becomes significantly related to well-child visits among more educated mothers $(r=.31$, $\mathrm{p}=.03)$. Within age categories, mothers' efficacy is still significantly associated with well-child visits among younger mothers (age 30 or under), with $r=.28$ and $p=.02$, but not among older mothers (over age 30 ).

These findings indicate that among younger, lower social class, and less educated mothers, those who are more efficacious are more likely to bring their children in for well-child care. On the other hand, among older, higher social class, and more educated mothers, efficacy does not play an important role in predicting children's well-child care.

None of the fathers' indices is significantly correlated with well-child care, even when controlling for age, social class, and education. Also, none of the parents' combined index scores is significantly associated with well-child care. Within educational categories, 
well-child care is correlated, at a very-close-to significant level, with parents' health concern among more educated parents $(\mathrm{r}=.26, \mathrm{p}=.054)$.

\section{Multivariate Analysis}

Multivariate regression analyses were used to examine the relative importance of mothers' and fathers' variables in explaining variance in well-child care visits. Two general types of regression models were constructed in terms of selection of independent variables in the models. For Model 1, only the four $\mathrm{HAB}$ indices were included; mothers', fathers', and parents' combined variables were entered separately. For Model 2, independent variables included four $\mathrm{HAB}$ indices and three control variables, entered separately for mothers, fathers and parents.

The results of the multivariate regression on well-child care visits are presented in Table $x$. First, Model 1 is not significant for mothers, fathers, and

\section{TABLE X}

MULTIVARIATE REGRESSION ON WELL-CHILD VISITS: MODEL 1 VERSUS MODEL 2

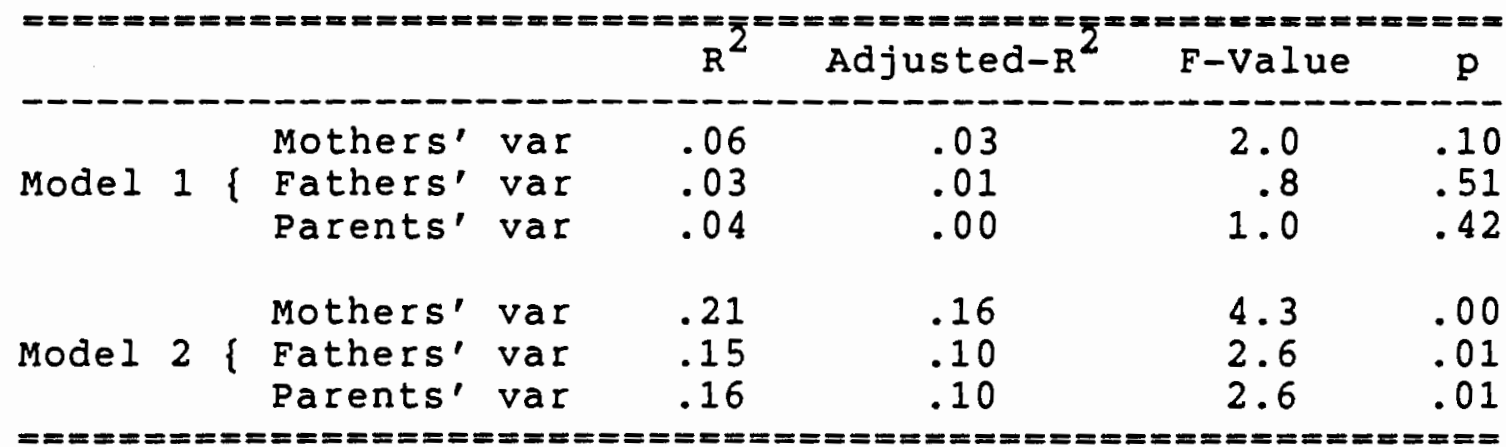


parents. Model 2 is statistically significant. In both Model 1 and Model 2, mothers' $R^{2}$ is bigger than fathers'. That is to say, more variance in well-child care visits is explained by mothers' $H A B$ indices and control variables in combination than is explained by fathers'.

Stepwise regression analyses were also used to assess the relative importance of mothers' and fathers' variables in predicating children's well-child care visits. Again, two general types of models were constructed. For Model 3 , the independent variables included both mothers' and fathers' $\mathrm{HAB}$ indices. Five variables were entered into the multivariate function at a selected level of probability for variable-entering ( $\left.P_{\text {in }}=.30, P_{\text {stay }}=.30\right)$. Table XI reveals that of these five variables mothers' efficacy is the best predictor of well-child care visits.

\section{TABLE XI}

STEPWISE REGRESSION ON WELL-CHILD VISITS: MODEL 3

\begin{tabular}{|c|c|c|c|c|}
\hline Step & Independent Variable & Partial-R ${ }^{2}$ & F-value & $\mathrm{p}$ \\
\hline 1 & Mothers' Efficacy & .038 & 4.2 & .04 \\
\hline 2 & $\begin{array}{l}\text { Mothers' Tendency to } \\
\text { Consult Physician }\end{array}$ & .015 & 1.7 & .20 \\
\hline 3 & $\begin{array}{l}\text { Fathers' skepticism } \\
\text { about physicians }\end{array}$ & .015 & 1.7 & .20 \\
\hline 4 & $\begin{array}{l}\text { Mothers' skepticism } \\
\text { about physician }\end{array}$ & .016 & 1.8 & .18 \\
\hline 5 & Fathers' Efficacy & .012 & 1.4 & .25 \\
\hline & & .0961 & $\left(R^{2}\right)$ & \\
\hline
\end{tabular}


Approximately 10 percent of the variance of well-child visits is explained by these five variables.

A similar stepwise regression analysis was conducted using mothers' and fathers' four $H A B$ indices and three control variables (Model 4). Table XII reveals that of these variables, mothers' education and self-reported social class are the best predictors of well-child care visits. About 21 percent of the variance in well-child visits is explained by the five variables entering the regression.

TABLE XII

STEPWISE REGRESSION ON WELL-CHILD VISITS: MODEL 4

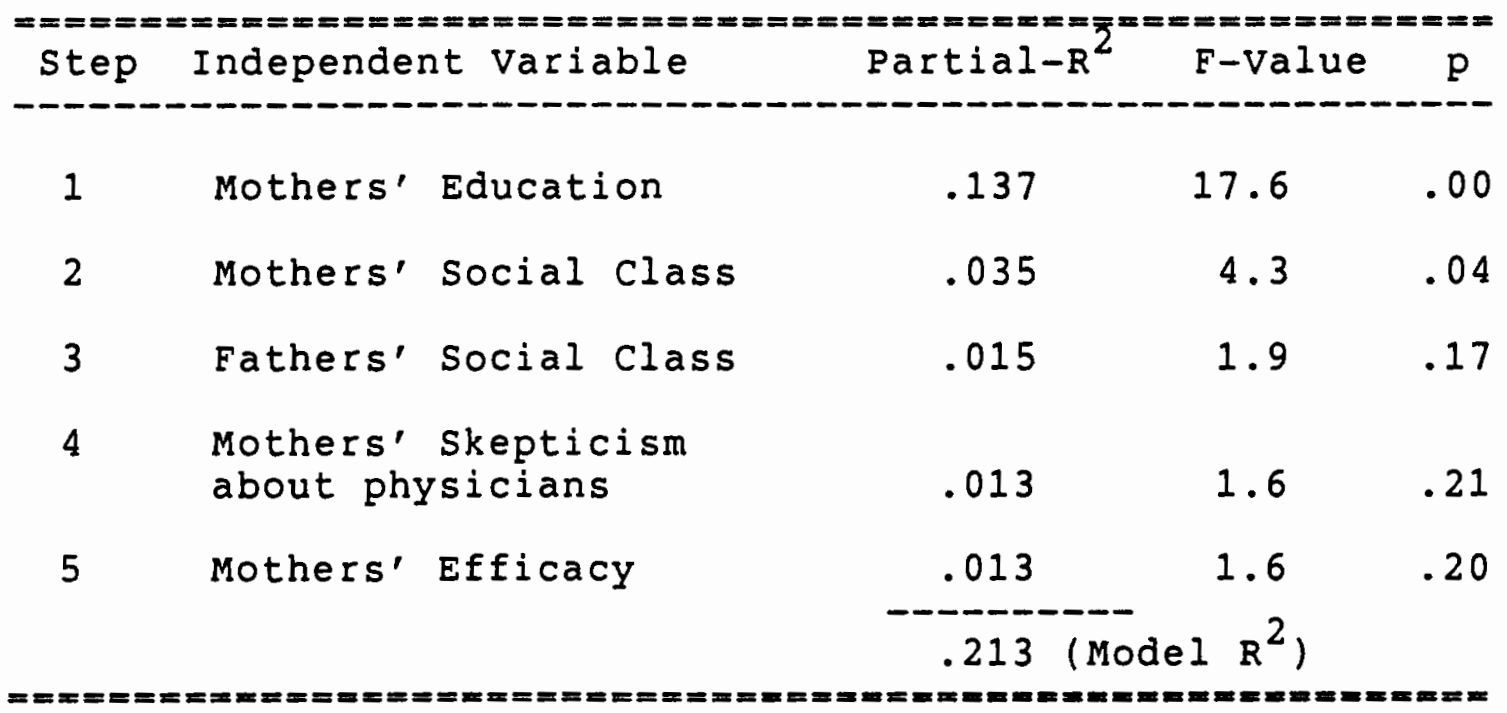

To summarize, both multivariate and stepwise regressions on well-child visits indicate that mothers' variables are more important predictors than fathers. In Model 1 and Model 2, mothers' $H A B$ indices explain more variance than either fathers' or parents' combined scores. 
In Model 3 and Model 4, more mothers' variables enter the regression, and mothers' variables accounts for the greater part of the explained variance of well-child visits in terms of partial $R^{2}$.

\section{HAB AND VACCINATIONS}

The children's level of immunization was measured in different ways: 1) the completion of each vaccine; 2) total number of five selected vaccine shots each child received; and 3) the completion of all these vaccines. A completion scale was constructed according to children's completion of each vaccine.

\section{Completion of Each Vaccine}

Table XIII shows the completion rates of five selected vaccines. Measles and polio had the highest completion rates, and mumps had the lowest rate. This might be because the vaccine was not very popular at that time. (Mumps vaccine did not come into use until 1967.)

\section{TABLE XIII}

\section{COMPLETION RATES OF FIVE SELECTED VACCINES}

\begin{tabular}{|c|c|c|c|}
\hline Vaccine & No shots & Some shots & Complete shots \\
\hline $\begin{array}{l}\text { DPT } \\
\text { Polio } \\
\text { Smalipox } \\
\text { Measles } \\
\text { Mumps }\end{array}$ & $\begin{array}{r}2(1.48) \\
4(2.88) \\
49(34.38) \\
19(13.38) \\
106(74.1 \%)\end{array}$ & $\begin{array}{c}39(27.38) \\
22(15.48) \\
N / A \\
N / A \\
N / A\end{array}$ & $\begin{aligned} 102 & (71.38) \\
117 & (81.88) \\
94 & (65.78) \\
128 & (86.78) \\
37 & (25.98)\end{aligned}$ \\
\hline
\end{tabular}


Cross-tabulation. Chi-square tests were employed to examine the relationship between children's completion of each vaccine and the $H A B$ indices of mothers, fathers, and parents. The HAB indices were collapsed into two categories: high versus low. Children were divided into two groups: those who had finished all recommended shots for each vaccination and those who had not. The results will be presented around four HAB scales.

1) Interest in and Concern with Health:

Table XIV show that children of mothers with high health concern have higher or about equal rates of completion in all vaccinations compared with mothers with

\section{TABLE XIV}

SUMMARY OF $X^{2}$ TESTS OF THE CROSS-TABULATION BETWEEN HEALTH CONCERN (HC) AND EACH VACCINE

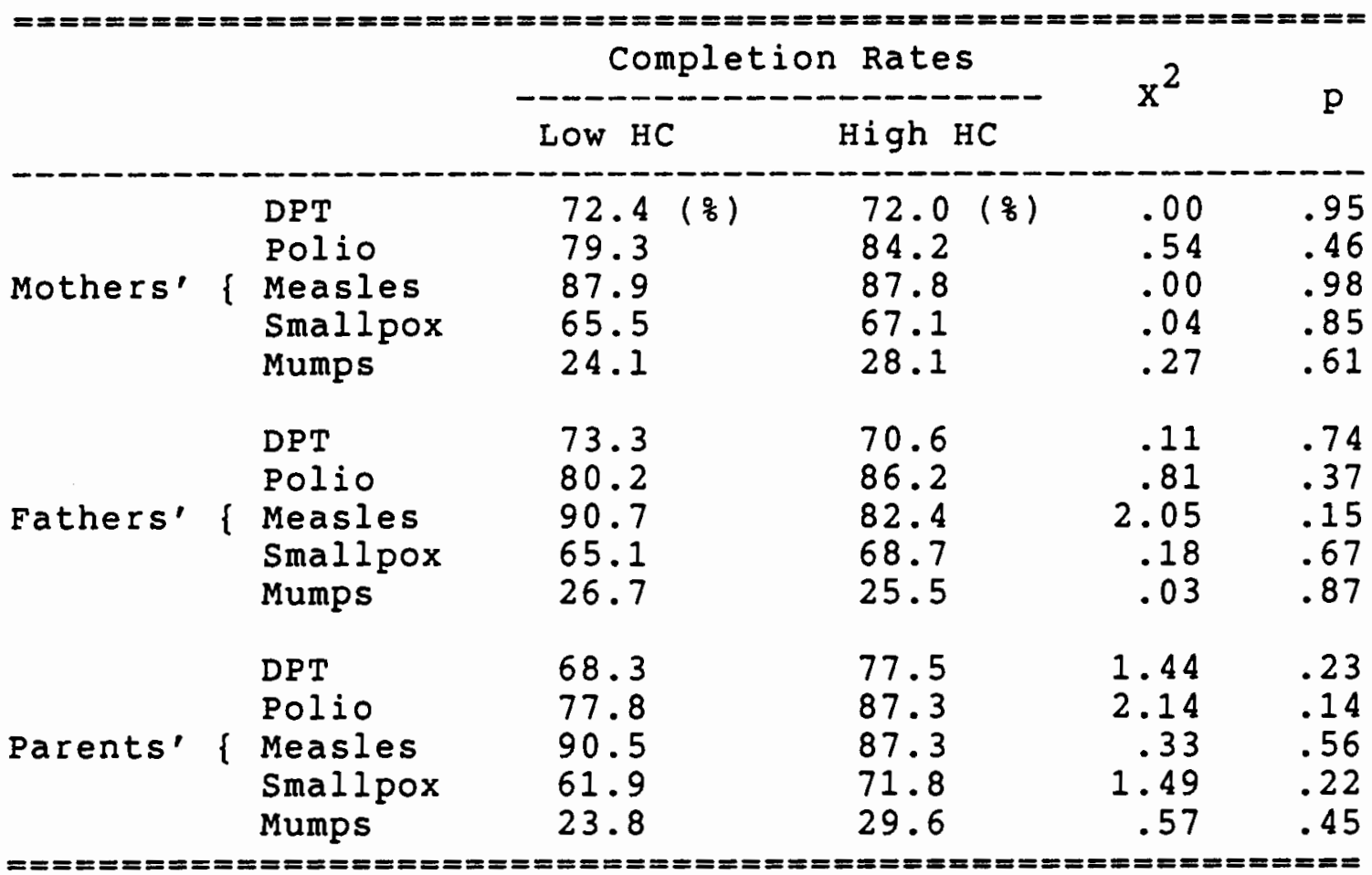


low health concern. Children of fathers with high health concern have higher rates of completion in polio and smallpox; but have lower rates of completion in measles and DPT; and are about equal in mumps. Parents' combined scales show that health concern is positively related to the completion of all vaccinations, with the exception of measles; the relationships are stronger than either mothers' or fathers' alone in terms of phi coefficients. But none of the Chi-square tests reaches significant level.

2) Skepticism about Physician:

As revealed in Table $x V$, children of mothers with a low degree of skepticism about physician have higher rates

\section{TABLE XV}

SUMMARY OF $\mathrm{X}^{2}$ TESTS OF THE CROSS-TABULATION BETWEEN SKEPTICISM (SK) AND EACH VACCINE

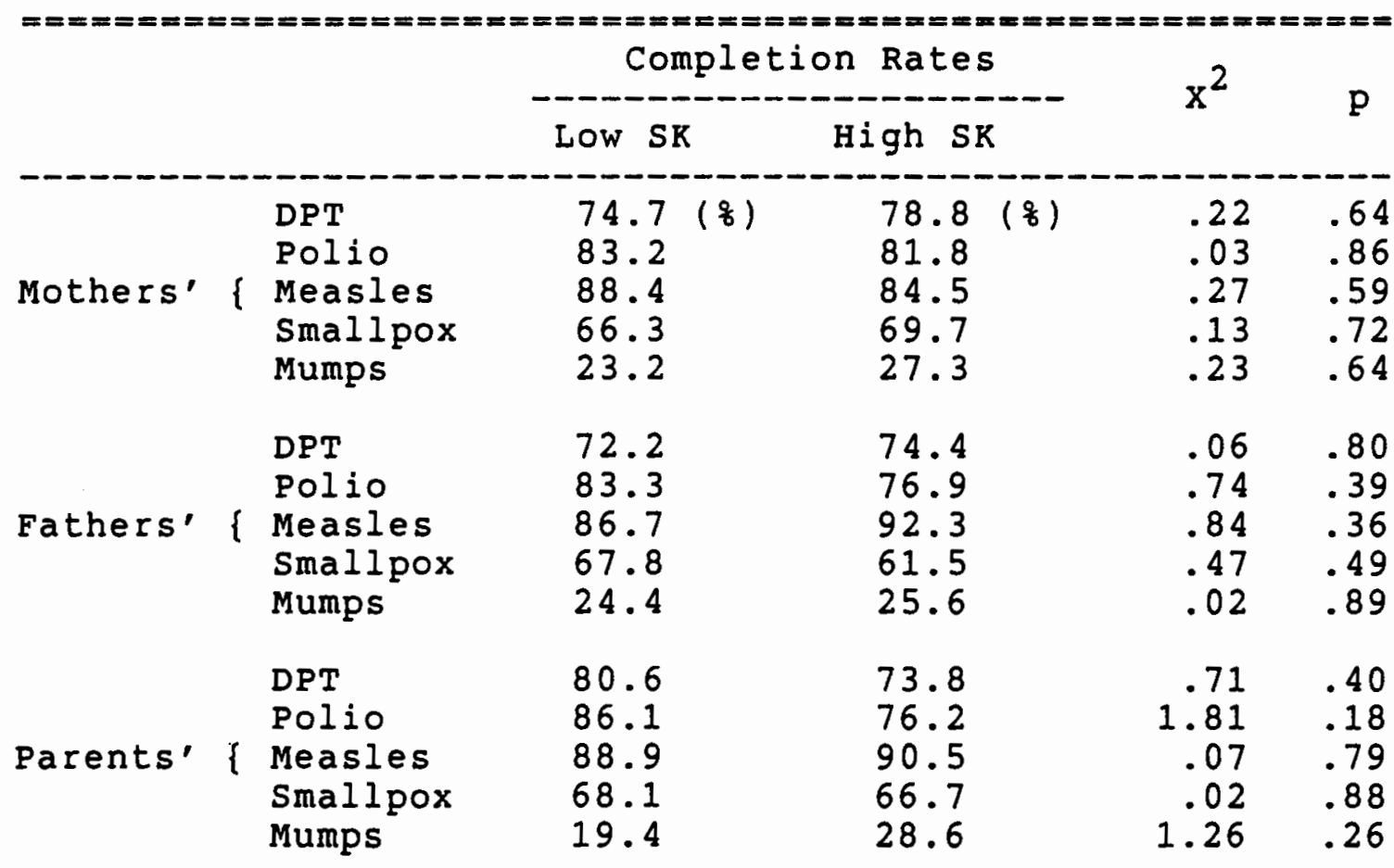


of completion in polio and measles, but lower rates of completion in DPT, smallpox, and mumps. Children of fathers with a low degree of skepticism have higher rates of completion in polio and smallpox; but lower rates of completion in all other vaccinations. Children of parents with low combined skepticism scales have higher rates of completions in DPT, polio, and smallpox; but lower rates in others. But none achieves statistical significance.

3) Tendency to consult the physician:

Children of mothers who tend to consult physician have lower rates of completion in all vaccinations, except for mumps (Table XVI). The same pattern also holds up for

\section{TABLE XVI}

SUMMARY OF $x^{2}$ TESTS OF THE CROSS-TABULATION BETWEEN TENDENCY TO CONSULT PHYSICIAN (TCP) AND EACH VACCINE

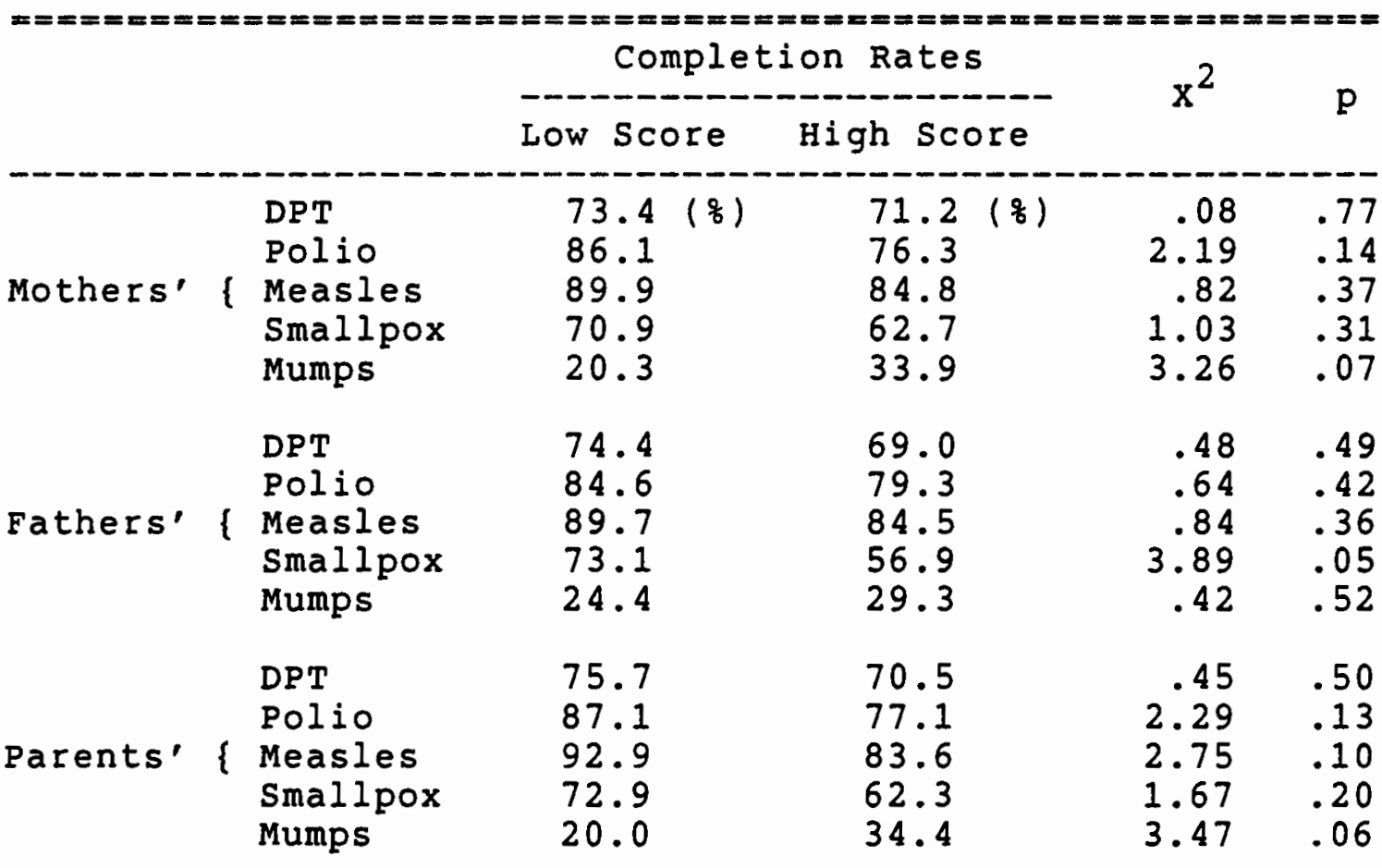


both fathers' and the combined parents' scales. This finding is contradictory to the hypothesis.

\section{4) Efficacy:}

Children of mothers with high perceived efficacy have higher or equal rates of completion in all vaccines (Table XVII). Children of fathers with high perceived efficacy have higher rates of completion in measles and smallpox. Children of parents with high combined efficacy scale have higher rates of completion in measles, but lower rates of completion in other vaccinations. However, none of the differences is statistically significant.

\section{TABLE XVII}

SUMMARY OF $x^{2}$ TESTS OF THE CROSS-TABULATION BETWEEN EFFICACY (EFF) AND EACH VACCINE

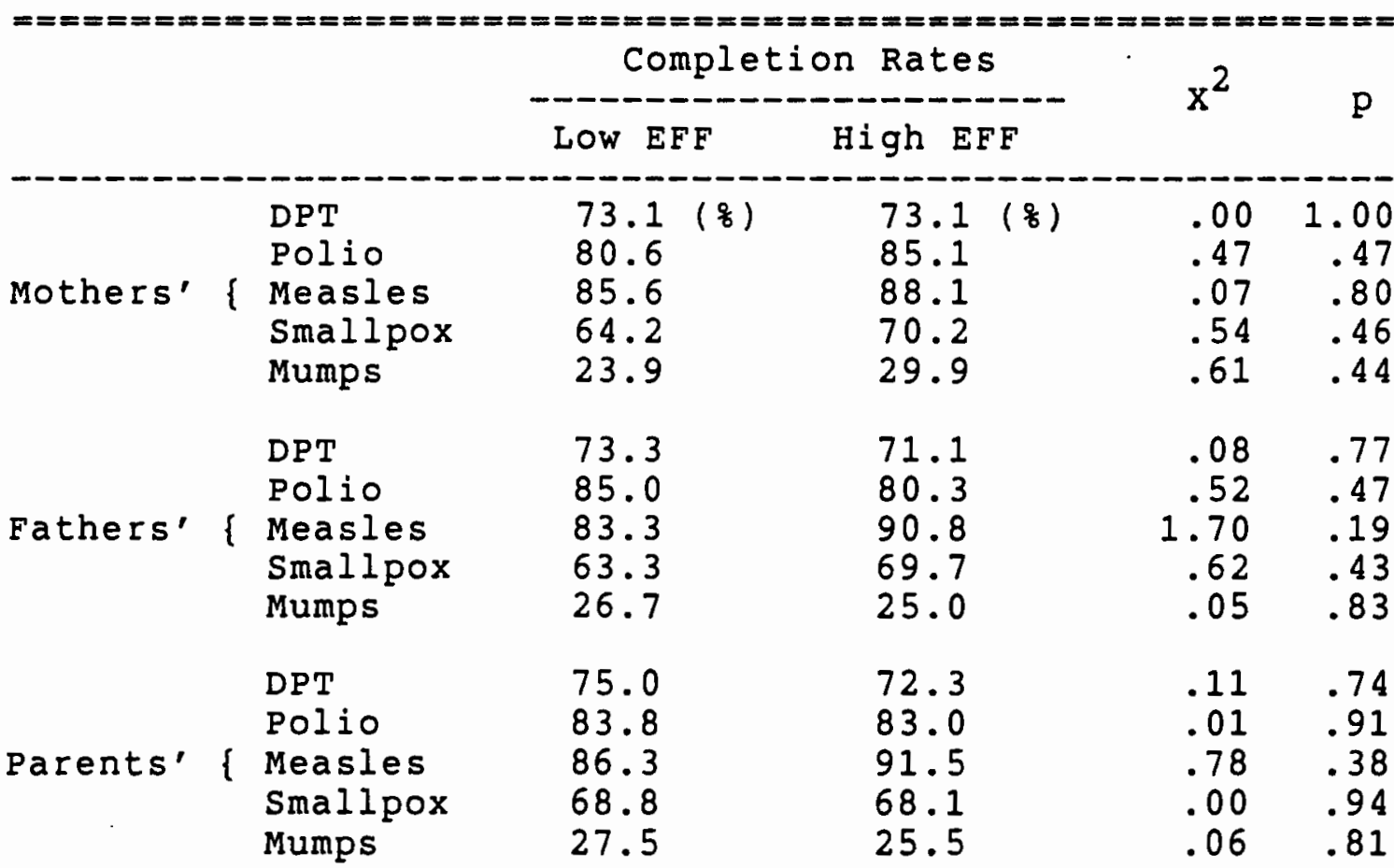


Stepwise Discriminant Analysis. Stepwise multiple discriminant analysis is a technique used to determine the relative importance of the included independent variables in discriminating between categories of the qualitative dependent variable. In this section, discriminant analysis was used to discriminate between categories of those who had completed a particular vaccine, and those who had not. Separate discriminant analysis runs were conducted for five selected vaccines. Two general models were set up in the process of variable inclusion. Model A included only mothers' and fathers' $A A B$ indices. For Model $B$, three control variables were added to model $A$.

1) Completion of Polio:

Table XVIII reveals that seven out of eight indices are entered into discriminant function. The only index that does not enter the function at the selected

\section{TABLE XVIII}

STEPWISE DISCRIMINANT ANALYSIS ON COMPLETION OF POLIO: MODEL A

\begin{tabular}{|c|c|c|c|c|c|}
\hline step & Independen & it Variable & Partial-R & F-Value & $p$ \\
\hline $\begin{array}{l}1 \\
2 \\
3 \\
4 \\
5 \\
6 \\
7\end{array}$ & $\begin{array}{l}\text { Mothers' } \\
\text { Fathers' } \\
\text { Fathers' } \\
\text { Mothers' } \\
\text { Fathers' } \\
\text { Fathers' } \\
\text { Mothers' }\end{array}$ & $\begin{array}{l}\text { Health Concern } \\
\text { Consult } \\
\text { Health Concern } \\
\text { Efficacy } \\
\text { Skepticism } \\
\text { Efficacy } \\
\text { Consult }\end{array}$ & $\begin{array}{l}.03 \\
.03 \\
.03 \\
.02 \\
.01 \\
.01 \\
.01\end{array}$ & $\begin{array}{l}2.9 \\
2.9 \\
2.9 \\
2.1 \\
1.5 \\
1.4 \\
1.3\end{array}$ & $\begin{array}{l}.09 \\
.09 \\
.09 \\
.14 \\
.23 \\
.24 \\
.26\end{array}$ \\
\hline
\end{tabular}


significant level is mothers' skepticism. The discriminant function explains 14 percent of the variance in completion of polio vaccine. The best (i.e., the first to enter) discriminator is mother's health concern. Table XIX shows that 25 percent of the variance in completion of polio was accounted for by all the independent variables when control variable are added into the model. In this model, the best discriminator is father's education, followed by father's age.

\section{TABLE XIX}

STEPWISE DISCRIMINANT ANALYSIS ON COMPLETION OF POLIO: MODEL B

\begin{tabular}{|c|c|c|c|c|c|}
\hline Step & Independen & t Variable & Partial-R & F-Value & $\mathrm{p}$ \\
\hline $\begin{array}{l}1 \\
2 \\
3 \\
4 \\
5 \\
6 \\
7 \\
8 \\
9\end{array}$ & $\begin{array}{l}\text { Fathers' } \\
\text { Fathers' } \\
\text { Mothers' } \\
\text { Mothers' } \\
\text { Mothers' } \\
\text { Fathers' } \\
\text { Mothers' } \\
\text { Fathers' } \\
\text { Fathers' }\end{array}$ & $\begin{array}{l}\text { education } \\
\text { age } \\
\text { Health concern } \\
\text { age } \\
\text { social class } \\
\text { Health Concern } \\
\text { Consult } \\
\text { Skepticism } \\
\text { Efficacy }\end{array}$ & $\begin{array}{l}.05 \\
.05 \\
.03 \\
.02 \\
.03 \\
.02 \\
.02 \\
.02 \\
.01\end{array}$ & $\begin{array}{l}5.5 \\
5.3 \\
3.5 \\
2.3 \\
2.8 \\
2.1 \\
2.2 \\
1.5 \\
1.1\end{array}$ & $\begin{array}{l}.02 \\
.02 \\
.06 \\
.13 \\
.10 \\
.15 \\
.14 \\
.22 \\
.28\end{array}$ \\
\hline
\end{tabular}

2) Completion of DPT. Table $x$ x reveals that only two variables enter the discriminant function at the pre-selected significant level. A very low percent of the variance (two percent) in completion of DPT is explained by father's education and mothers' efficacy. Table XxI shows with the expanded list of variables on the model that 10 
percent of the variance in completion of DPT is accounted for by fathers' education, mothers' and fathers' social

class. Neither mothers' nor fathers' HAB indices enter the discriminant equation when the control variables are present.

TABLE XX

STEPWISE DISCRIMINANT ANALYSIS ON COMPLETION OF DPT: Model A

\begin{tabular}{|c|c|c|c|c|c|}
\hline Step & Independen & t Variable & Partial- $R^{2}$ & F-value & $p$ \\
\hline $\begin{array}{l}1 \\
2\end{array}$ & $\begin{array}{l}\text { Fathers' } \\
\text { Mothers' }\end{array}$ & $\begin{array}{l}\text { Health Concern } \\
\text { Efficacy }\end{array}$ & $\begin{array}{l}.01 \\
.01\end{array}$ & $\begin{array}{l}1.4 \\
1.2\end{array}$ & $\begin{array}{l}.25 \\
.28\end{array}$ \\
\hline
\end{tabular}

TABLE XXI

STEPWISE DISCRIMINANT ANALYSIS ON COMPLETION OF DPT: MODEL B

\begin{tabular}{|c|c|c|c|c|c|}
\hline Step & Independen & it variable & Partial-R & F-Value & $\mathrm{p}$ \\
\hline $\begin{array}{l}1 \\
2 \\
3\end{array}$ & $\begin{array}{l}\text { Fathers' } \\
\text { Mothers' } \\
\text { Fathers' }\end{array}$ & $\begin{array}{l}\text { education } \\
\text { social class } \\
\text { social class }\end{array}$ & $\begin{array}{l}.05 \\
.03 \\
.02\end{array}$ & $\begin{array}{l}5.5 \\
2.8 \\
2.8\end{array}$ & $\begin{array}{l}.03 \\
.06 \\
.20\end{array}$ \\
\hline
\end{tabular}

3) Completion of Measles

For Model $A$, mothers' tendency to consult physician

is the only variable entering the discriminant equation among all mothers' and fathers' $\mathrm{HAB}$ indices. It explains four percent of the variance in completion of measles (Table XXII). For Model B, the entered variables include 
mothers' tendency to consult physician and mothers' social class. These two variables explain seven percent of the variance in completion of measles (Table XxIII).

\section{TABLE XXII}

STEPWISE DISCRIMINANT ANALYSIS ON COMPLETION OF MEASLES: MODEL A

\begin{tabular}{|c|c|c|c|c|}
\hline Step & Independent variable & Partial $-R^{2}$ & F-value & $\mathrm{p}$ \\
\hline 1 & Mothers' Consult & .04 & 4.9 & .03 \\
\hline
\end{tabular}

TABLE XXIII

STEPWISE DISCRIMINANT ANALYSIS ON COMPLETION OF MEASLES: MODEL B

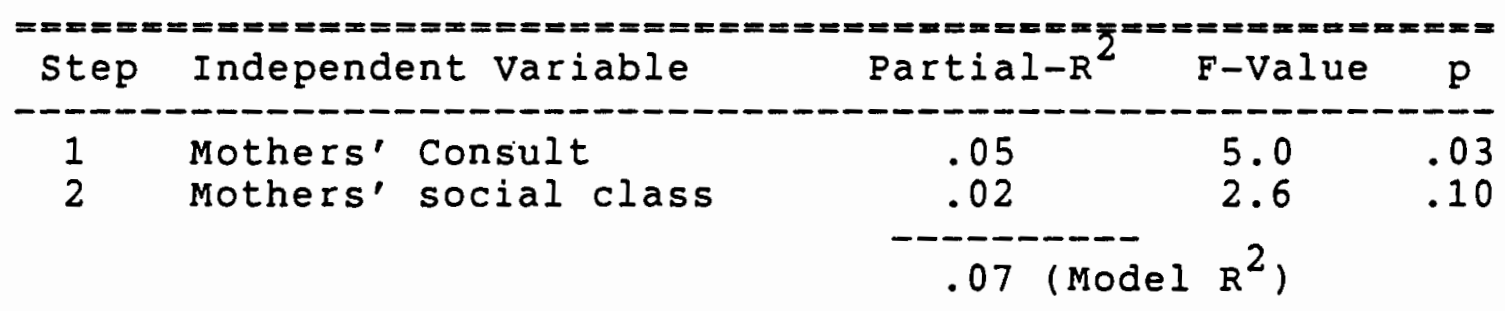

4) Completion of Smallpox

Mothers' efficacy is the only variable entering the discriminant equation. It explains two percent of the variance in completion of smallpox (Table XXIV). For Model B, fathers' education, fathers' and mothers' social class are the only variables which enter the equation. They, together, explain 7 percent of the variance in completion of smallpox (Table XXV). None of the mothers' and fathers' $H A B$ indices enter the discriminant equation. 
TABLE XXIV

STEPWISE DISCRIMINANT ANALYSIS ON COMPLETION OF SMALLPOX: MODEL A

\begin{tabular}{|c|c|c|c|c|}
\hline step & Independent variable & Partial-R ${ }^{2}$ & F-Value & $\mathrm{p}$ \\
\hline 1 & Mothers' Efficacy & .02 & 1.9 & .17 \\
\hline
\end{tabular}

TABLE XXV

STEPWISE DISCRIMINANT ANALYSIS ON COMPLETION OF SMALLPOX: Model B

\begin{tabular}{|c|c|c|c|c|c|}
\hline step & Independen & t Variable & Partial-R $\mathrm{R}^{2}$ & F-Value & $\mathrm{p}$ \\
\hline $\begin{array}{l}1 \\
2 \\
3\end{array}$ & $\begin{array}{l}\text { Fathers' } \\
\text { Fathers' } \\
\text { Mothers }\end{array}$ & $\begin{array}{l}\text { education } \\
\text { social class } \\
\text { social class }\end{array}$ & $\begin{array}{l}.03 \\
.02 \\
.02\end{array}$ & $\begin{array}{l}3.0 \\
2.2 \\
1.7\end{array}$ & $\begin{array}{l}.09 \\
.14 \\
.19\end{array}$ \\
\hline
\end{tabular}

5) Completion of Mumps

For Model A, four variables enter the equation. Mothers' tendency to consult physician is the best discriminator. About 12 percent of the variance in completion of mumps is explained by these four variables (Table XXVI). For Model B (Table XXVII), five variables entered the discriminant equation. They together explain 22 percent of the variance in completion of mumps. Mothers' tendency to consult physician is still the best discriminator. 
TABLE XXVI

STEPWISE DISCRIMINANT ANAIYSIS ON COMPLETION OF MUMPS: MODEI A

\begin{tabular}{|c|c|c|c|c|c|}
\hline Step & Independen & it variable & Partial-R & F-Value & $\mathrm{p}$ \\
\hline $\begin{array}{l}1 \\
2 \\
3 \\
4\end{array}$ & $\begin{array}{l}\text { Mothers' } \\
\text { Mothers' } \\
\text { Mothers' } \\
\text { Fathers' }\end{array}$ & $\begin{array}{l}\text { Consult } \\
\text { Efficacy } \\
\text { Skepticism } \\
\text { Consult }\end{array}$ & $\begin{array}{l}.07 \\
.02 \\
.02 \\
.01\end{array}$ & $\begin{array}{l}7.6 \\
2.3 \\
1.9 \\
1.2\end{array}$ & $\begin{array}{r}.01 \\
.12 \\
.17 \\
.29\end{array}$ \\
\hline
\end{tabular}

\section{TABLE XXVII}

STEPWISE DISCRIMINANT ANALYSIS ON COMPLETION OF MUMPS: MODEL B

\begin{tabular}{|c|c|c|c|c|c|}
\hline step & Independen & it Variable & Partial-R ${ }^{2}$ & F-Value & $\mathrm{p}$ \\
\hline $\begin{array}{l}1 \\
2 \\
3 \\
4 \\
5\end{array}$ & $\begin{array}{l}\text { Mothers' } \\
\text { Fathers' } \\
\text { Mothers' } \\
\text { Fathers' } \\
\text { Mothers' }\end{array}$ & $\begin{array}{l}\text { Consult } \\
\text { education } \\
\text { age } \\
\text { Consult } \\
\text { social class }\end{array}$ & $\begin{array}{l}.07 \\
.07 \\
.04 \\
.02 \\
.02\end{array}$ & $\begin{array}{l}7.7 \\
7.2 \\
3.7 \\
2.5 \\
2.1\end{array}$ & $\begin{array}{l}.01 \\
.01 \\
.06 \\
.12 \\
.15\end{array}$ \\
\hline
\end{tabular}

Total Number of Vaccinations

Total number of vaccinations was computed for all five selected vaccines. The frequency distribution is presented in Table XXVIII. The mean and median for total number of vaccinations are 8.9 and 9 , respectively. It is obvious that the distribution is a bit skewed to the right, with most cases clustering around the high score.

Pearson Correlations. Table XXIX shows the relationships between the total number of vaccinations 


\section{TABLE XXVIII}

FREQUENCY DISTRIBUTION OF TOTAL NUMBER OF VACCINATIONS

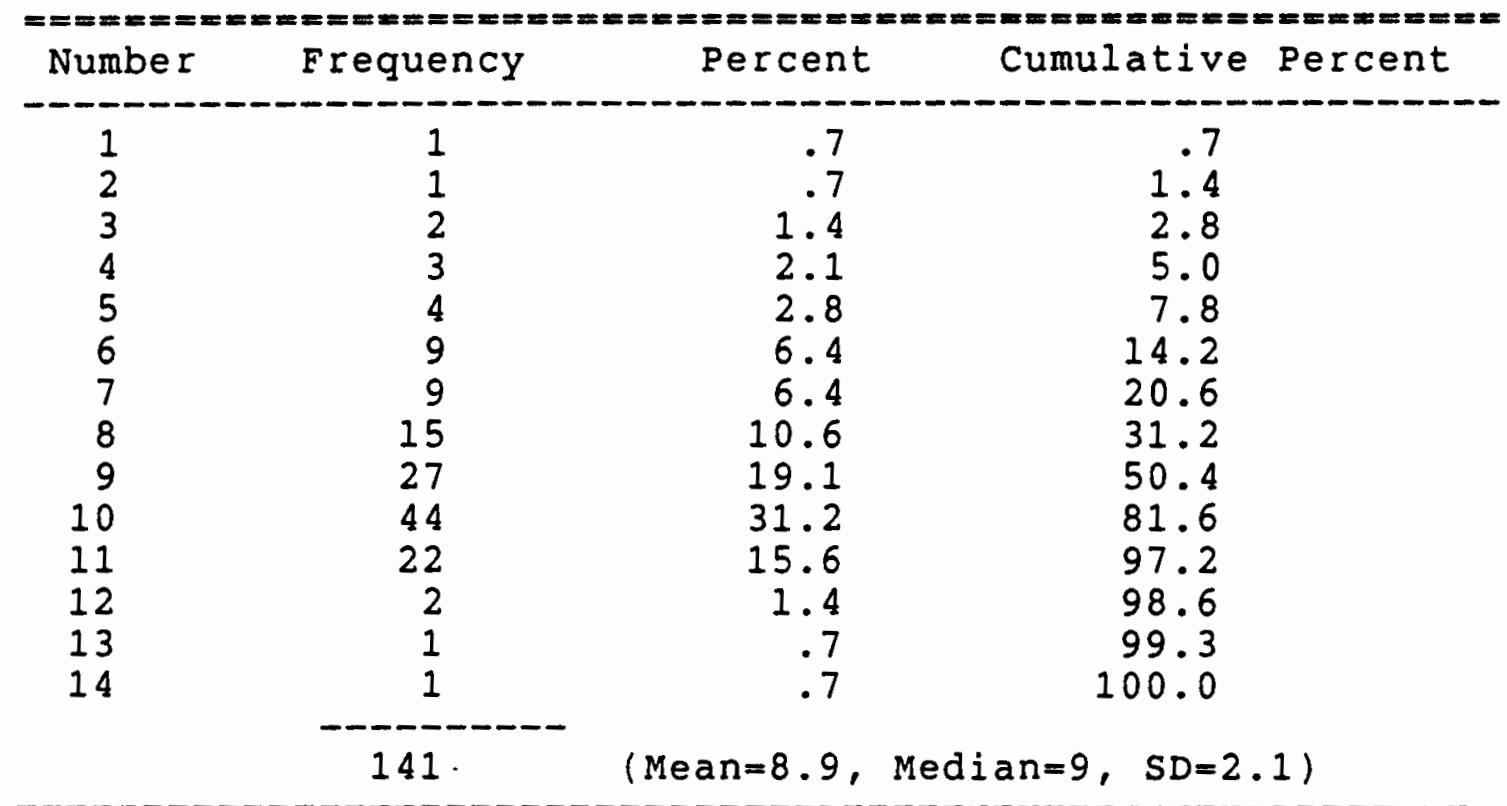

obtained and the characteristics of mothers, fathers and parents combined. The total number of vaccinations is significantly correlated with mothers' social class and parents' combined score of education, and very significantly associated with fathers' education. None of the $\mathrm{HAB}$ indices is significantly associated with the total number of vaccinations.

Within educational categories, mothers' efficacy becomes more highly correlated with the number of vaccinations among less educated mothers, but not quite reaching a significant level $(r=.16, p=.14)$; mothers' high skepticism is significantly associated with the number of vaccinations obtained among more educated mothers ( $r=.29$, 


\section{TABLE XXIX}

CORRELATION BETWEEN MOTHERS', FATHERS, AND PARENTS' CHARACTERISTICS AND TOTAL NUMBER OF VACCINATIONS OBTAINED

\begin{tabular}{|c|c|c|c|}
\hline & $\begin{array}{c}\text { Vaccines and } \\
\text { Mothers' }\end{array}$ & $\begin{array}{c}\text { Vaccines and } \\
\text { Fathers' }\end{array}$ & $\begin{array}{c}\text { Vaccines and } \\
\text { Parents' }\end{array}$ \\
\hline $\begin{array}{l}\text { Health } \\
\text { Concern }\end{array}$ & -.02 & -.06 & -.00 \\
\hline skepticism & .08 & .05 & .05 \\
\hline $\begin{array}{l}\text { Consulting } \\
\text { Physician }\end{array}$ & -.04 & -.04 & -.04 \\
\hline Efficacy & .11 & -.04 & .03 \\
\hline Education & .12 & $.24 \#$ & $.19 *$ \\
\hline Social Class & $.19 *$ & -.07 & .08 \\
\hline $\begin{array}{l}\text { Age } \\
\begin{aligned}= & ========= \\
& \star \text { denotes } \\
& \# \text { indicate }\end{aligned}\end{array}$ & $\begin{array}{l}\quad-.00 \\
====== \\
.05 \\
P<.01\end{array}$ & $\begin{aligned} & -.07 \\
= & ==2=\end{aligned}$ & 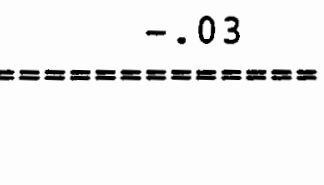 \\
\hline
\end{tabular}

$\mathrm{p}=.04)$; parents' combined skepticism is very significantly associated with the vaccinations among more educated parents $(r=.40, p=.00)$.

Within social class categories, the relationship between mothers' efficacy and the number of vaccinations approaches a significant level $(\mathrm{r}=.20, \mathrm{p}=.09)$ among low social class mothers; among high social class fathers, fathers' health concern is significantly and negatively correlated with the vaccinations $(r=-.33, p=.02)$.

Within age categories, mothers' efficacy becomes more highly correlated with the vaccinations among younger mothers $(I=.17, p=.16)$; among younger fathers, the positive 
relationship between fathers' skepticism and the number of vaccinations approaches a significant level $(r=.25, p=.09)$. Multivariate Regression. Multivariate regression analyses were used to assess the relative importance of mothers' and fathers' variables in explaining variation in total numbers of vaccinations. The results of the regression are presented in Table xxx. For Model 1, only $H A B$ indices were included. The regression analyses were run separately for mothers, fathers, and parents combined variables. Model 1 is not statistically significant for mothers, fathers, and parents. Mothers' $R^{2}$ is a bit larger than fathers' and parents'.

TABLE XXX

MULTIVARIATE REGRESSION ON TOTAL NUMBER OF VACCINATIONS: MODEL 1 VERSUS MODEL 2

\begin{tabular}{|c|c|c|c|c|c|c|c|}
\hline & & & & $\mathrm{R}^{2}$ & Adjusted $-R^{2}$ & F-Value & $\mathrm{p}$ \\
\hline Model & 11 & $\begin{array}{l}\text { Mothers' } \\
\text { Fathers' } \\
\text { Parents' }\end{array}$ & $\begin{array}{l}\text { var } \\
\text { var } \\
\text { var }\end{array}$ & $\begin{array}{l}.03 \\
.01 \\
.02\end{array}$ & $\begin{array}{l}-.01 \\
-.03 \\
-.02\end{array}$ & $\begin{array}{l}.75 \\
.16 \\
.60\end{array}$ & $\begin{array}{l}.56 \\
.96 \\
.67\end{array}$ \\
\hline Mode 1 & 2\{ & $\begin{array}{l}\text { Mothers' } \\
\text { Fathers' } \\
\text { Parents' }\end{array}$ & $\begin{array}{l}\operatorname{var} \\
\operatorname{var} \\
\operatorname{var}\end{array}$ & $\begin{array}{l}.06 \\
.10 \\
.07\end{array}$ & $\begin{array}{l}.01 \\
.04 \\
.00\end{array}$ & $\begin{array}{l}1.1 \\
1.7 \\
1.0\end{array}$ & $\begin{array}{l}.37 \\
.10 \\
.41\end{array}$ \\
\hline
\end{tabular}

For model 2, four $H A B$ indices and three control variables are included in the model. None of the variables in the model is statistically significant, though the fathers' variables approaches a significant level. In terms of $R^{2}$, fathers' variables explain more variance in 
total number of vaccinations than mothers' or parents' combined variables.

Separate stepwise regression runs were employed to assess the relative importance of mothers' and fathers' variables in predicting children's total number of vaccinations. For model 3, mothers' and fathers' $H A B$ indices are included (Table XXXI). Only one (mothers' efficacy) out of eight variables enters the regression equation. A very low proportion (1.5\%) of the variance in total number of vaccinations is explained by mothers' efficacy. For Model 4 (Table XXXII), mothers' and fathers' control variables are added to Model 3; only fathers' education and mothers' social class enter the equation. This model explains eight percent of the variance in total number of vaccinations.

\section{TABLE XXXI}

STEPWISE REGRESSION ON TOTAL NUMBER OF VACCINATIONS: MODEL 3

\begin{tabular}{|c|c|c|c|c|}
\hline step & Independent Variable & Partial $-R^{2}$ & F-Value & $\mathrm{p}$ \\
\hline 1 & Mothers' Efficacy & .015 & 1.6 & .21 \\
\hline
\end{tabular}

Vaccine Completion scale

The completion scale was derived from the completion state of five selected vaccines. The completion of each vaccination was scored according to the number of shots the 


\section{TABLE XXXII}

STEPWISE REGRESSION ON TOTAL NUMBER OF VACCINATIONS: MODEL 4

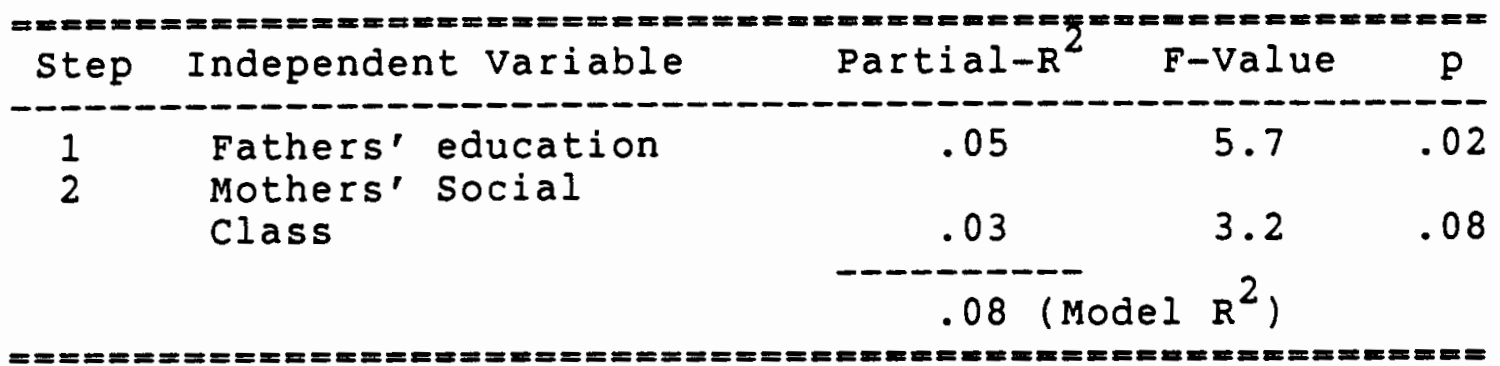

children received for each vaccine as compared to the recommended shots: a score of 2 representing finishing all recommended shots, 1 indicating getting some of the recommended shots, and 0 meaning not getting any of the recommended shots for the indicated vaccine. The total score for completion of all vaccines was calculated by simply adding up the scores for each of the five vaccines. Table XXXIII presents the frequency distribution of the

\section{TABLE XXXIII}

FREQUENCY DISTRIBUTION OF VACCINATION COMPLETION SCALE

\begin{tabular}{|c|c|c|c|}
\hline score & Frequency & Percent & Cumulative Percent \\
\hline $\begin{array}{r}0 \\
1 \\
2 \\
3 \\
4 \\
5 \\
6 \\
7 \\
8 \\
9 \\
10\end{array}$ & $\begin{array}{r}2 \\
1 \\
5 \\
2 \\
5 \\
10 \\
30 \\
12 \\
50 \\
2 \\
24 \\
\hdashline-143\end{array}$ & $\begin{array}{r}1 \cdot 4 \\
.7 \\
3 \cdot 5 \\
1 \cdot 4 \\
3 \cdot 5 \\
7 \cdot 0 \\
21 \cdot 0 \\
8 \cdot 4 \\
35 \cdot 0 \\
1 \cdot 4 \\
16 \cdot 8 \\
\text { (Mean=7 }\end{array}$ & $\begin{array}{c}1.4 \\
2.1 \\
5.6 \\
7.0 \\
10.5 \\
17.5 \\
38.5 \\
46.9 \\
81.8 \\
83.2 \\
100.0 \\
\text { Median=8, SD=2.2) }\end{array}$ \\
\hline
\end{tabular}


completion score. The mean and median of the score are seven and eight, respectively. The distribution of the score is very skewed to the right.

Pearson correlations. The relationships between mothers', fathers', and parents' $H A B$ and the completion scale for five selected vaccines are presented in Table XXXIV. Pearson correlation coefficients show that the only

\section{TABLE XXXIV}

CORRELATION BETWEEN MOTHERS', FATHERS', AND PARENTS' HAB INDICES AND COMPLETION SCALE

\begin{tabular}{|c|c|c|c|}
\hline & Mothers' & Fathers' & Parents' \\
\hline $\begin{array}{l}\text { Health } \\
\text { Concern }\end{array}$ & .04 & -.05 & .04 \\
\hline skepticism & .05 & -.01 & .02 \\
\hline $\begin{array}{l}\text { Consulting } \\
\text { Physician }\end{array}$ & .01 & -.03 & .02 \\
\hline Efficacy & $.18 *$ & .02 & .08 \\
\hline Education & $.21 \#$ & $.29 \#$ & $.25 \#$ \\
\hline Social Class & $.22 \#$ & -.08 & .11 \\
\hline $\begin{array}{l}\text { Age } \\
\begin{aligned}== & ======== \\
& * \text { denotes } \\
& \# \text { indicate }\end{aligned}\end{array}$ & $\begin{array}{l}-.08 \\
====== \\
05 \\
.01\end{array}$ & $\begin{array}{l}-.13 \\
==-==0=\end{array}$ & $\begin{array}{l}-.11 \\
== \pm==0\end{array}$ \\
\hline
\end{tabular}

association reaching a significant level $(r=.18, p=.03)$ is between mothers' efficacy and completion of all vaccinations. There is no significant association between other $\mathrm{HAB}$ indices for either parent or both combined and 
completion of vaccination. Of the control variables, education of mothers, fathers, and parents is each significantly related to the completion of vaccinations. Mothers' self-reported social class is also predictive of the completion of vaccines.

Within educational categories, mothers' efficacy is significantly correlated with the completion scale ( $r=.21$, $\mathrm{p}=.05$ ) among less educated mothers; among more educated mothers, mothers' skepticism is significantly correlated with the completion scale $(r=.35, p=.01)$.

Within social class categories, none of the HAB indices is significantly correlated with the completion scale among either high or low social class mothers, fathers, or parents. Within age categories, mothers' efficacy is more highly correlated with the completion scale ( $r=.27, p=.02$ ) among younger mothers ( 30 or younger); among older (over age 30 ) parents, the relationship between parents' combined health concern and the completion scale becomes stronger $(r=.20, p=.08)$.

\section{Multivariate Regression. Multivariate regression} analyses were used to assess the relative importance of mothers' and fathers' variables in explaining variation in completion of five selected vaccines. The results of the regression are presented in Table XXXV. For Model 1, only $\mathrm{HAB}$ indices were included. The regression analyses were run separately for mothers', fathers', and parents' combined variables. Model $l$ is not statistically 
significant for mothers, fathers, or parents. $R^{2}$ 's for mothers, fathers, and parents are about the same.

For model 2, four $H A B$ indices and three control

variables were included. Only the fathers' combined variables are statistically significant, though both mothers' combined variables and parents' combined variables approach a significant level. In terms of $R^{2}$, fathers' variables explain more variance in the completion scale than mothers' or parents' combined variables.

\section{TABLE XXXV}

MULTIVARIATE REGRESSION ON COMPLETION SCALE: MODEL 1 VERSUS MODEL 2

\begin{tabular}{|c|c|c|c|c|c|c|}
\hline & & & $\mathrm{R}^{2}$ & Adjusted-R ${ }^{2}$ & F-Value & $\mathrm{p}$ \\
\hline Model 1\{ & $\begin{array}{l}\text { Mothers' } \\
\text { Fathers' } \\
\text { Parents' }\end{array}$ & $\begin{array}{l}\text { var } \\
\text { var } \\
\text { var }\end{array}$ & $\begin{array}{l}.02 \\
.01 \\
.01\end{array}$ & $\begin{array}{l}-.01 \\
-.02 \\
-.03\end{array}$ & $\begin{array}{r}.72 \\
.38 \\
.26\end{array}$ & $\begin{array}{l}.580 \\
.821 \\
.903\end{array}$ \\
\hline Model 2 & $\begin{array}{l}\text { Mothers' } \\
\text { Fathers' } \\
\text { Parents' }\end{array}$ & $\begin{array}{l}\text { var } \\
\text { var } \\
\text { var }\end{array}$ & $\begin{array}{r}.10 \\
.16 \\
.12\end{array}$ & $\begin{array}{r}.05 \\
.11 \\
.06\end{array}$ & $\begin{array}{l}1.8 \\
3.1 \\
2.1\end{array}$ & $\begin{array}{l}.086 \\
.005 \\
.077\end{array}$ \\
\hline
\end{tabular}

Stepwise regression was used to assess the relative importance of mothers' and fathers' variables in predicting scores on the completion scale. For model 3 (Table XxxVI), mothers' and fathers' $\mathrm{HAB}$ indices are included. Only mothers' efficacy index enters the regression equation. A very low proportion (3.3\%) of the variance in the completion scale is explained by mothers' efficacy. For Model 4 (Table XXXVII), mothers' and fathers' control 
variables are added to Model 3; fathers' education, mothers' social class, fathers' age, and fathers' health concern enter the equation, but only father's education and mothers' social class are statistically significant. While this model explains 16 percent of the variance in the completion scale, two variables, fathers' education and mothers' social class, account for nearly all of the variance.

TABLE XXXVI

STEPWISE REGRESSION ON COMPLETION SCALE: MODEL 3

\begin{tabular}{|c|c|c|c|c|}
\hline Step & Independent Variable & Partial-R & F-Value & $p$ \\
\hline 1 & Mothers' Efficacy & .033 & 3.5 & .06 \\
\hline
\end{tabular}

TABLE XXXVII

STEPWISE REGRESSION ON COMPLETION SCALE: MODEL 4

\begin{tabular}{|c|c|c|c|c|c|}
\hline Step & Independer & nt Variable & Partial-R & F-Value & $\mathrm{p}$ \\
\hline $\begin{array}{l}1 \\
2 \\
3 \\
4\end{array}$ & $\begin{array}{l}\text { Fathers' } \\
\text { Mothers' } \\
\text { Fathers' } \\
\text { Fathers' }\end{array}$ & $\begin{array}{l}\text { education } \\
\text { social class } \\
\text { age } \\
\text { Health concern }\end{array}$ & $\begin{array}{l}.09 \\
.05 \\
.01 \\
.01\end{array}$ & $\begin{array}{r}10.2 \\
6.1 \\
1.5 \\
1.2\end{array}$ & $\begin{array}{l}.00 \\
.01 \\
.22 \\
.28\end{array}$ \\
\hline
\end{tabular}

Stepwise Discriminant Analysis. Stepwise multiple discriminant analysis was used to determine the relative importance of the included independent variables in discriminating between categories of those children who had 
finished all five vaccines and those who not. Separate discriminant analyses were conducted for the completion scale. Two general models were set up in the process of variable inclusion. Model A included only mothers' and fathers' HAB indices. For Model B, three control variables were added to model $A$.

Table XXXVIII reveals that only two mothers' indices enter the discriminant function at the selected significant level. The discriminant function explains 6.6 percent of variance in the completion of all five vaccines. The best discriminator is mothers' tendency to consult physician. Table XXXIX shows that 18 percent of the variance is accounted for by all the independent variables when control variable are added into the model. The best discriminator is still mothers' tendency to consult physician.

\section{TABLE XXXVIII}

STEPWISE DISCRIMINANT ANALYSIS ON COMPLETION SCALE: MODEL A

\begin{tabular}{|c|c|c|c|c|}
\hline Step & Independent Variable & Partial-R & F-Value & $\mathrm{p}$ \\
\hline$\frac{1}{2}$ & $\begin{array}{l}\text { Mothers' Consult } \\
\text { Mothers' Efficacy }\end{array}$ & $\begin{array}{l}.046 \\
.020\end{array}$ & $\begin{array}{l}5.07 \\
2.17\end{array}$ & $\begin{array}{r}.026 \\
.144\end{array}$ \\
\hline
\end{tabular}




\section{TABLE XXXIX}

STEPWISE DISCRIMINANT ANALYSIS ON COMPIETION SCALE: MODEL B

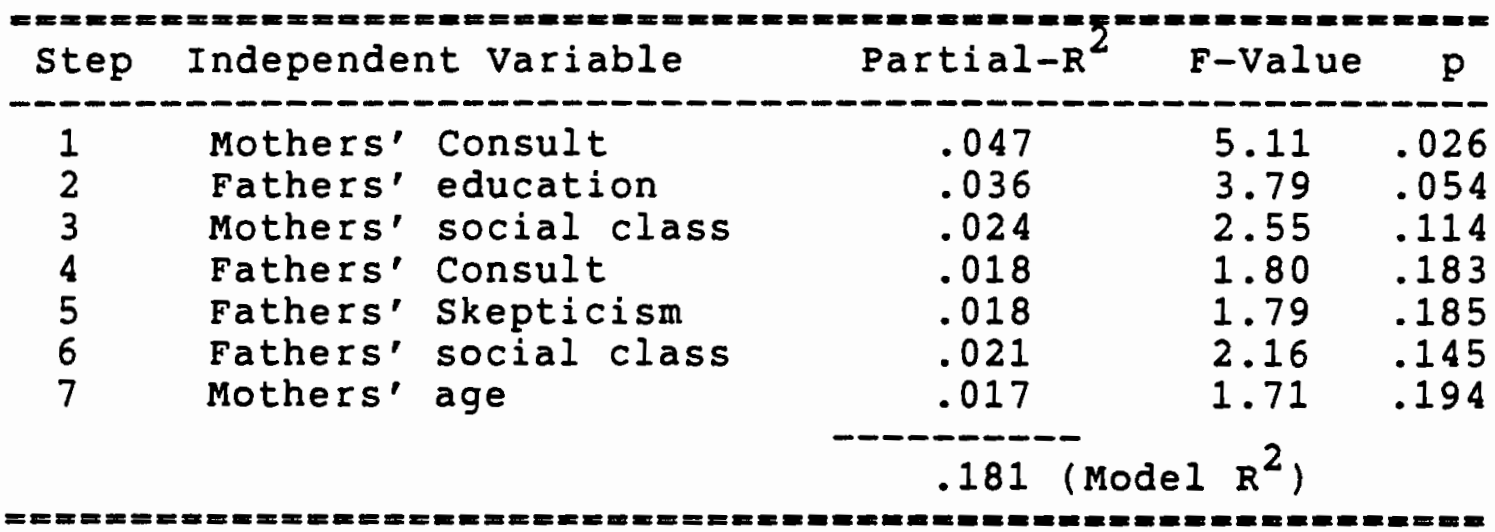


CHAPTER IV

\section{DISCUSSION AND CONCLUSION}

This chapter will be divided into four sections. The first section will discuss the hypotheses of the study. The second section takes up the limitations and weaknesses of this research. The third section will address the implication of the study. The last section will talk over the recommendations for future research.

\section{DISCUSSION OF THE HYPOTHESES}

In the first chapter, four specific hypotheses were formulated under the primary hypothesis, which states that children's preventive care visits are associated with parents' health attitudes and beliefs. The findings in the study are, in general, not clear in supporting the hypotheses. Each specific hypothesis will be discussed below.

Interest in and Concern with Health

Hypothesis I states: Children's preventive care visits are positively correlated with parents' interest in and concern with health. The findings from this study do not seem to support this hypothesis. First, well-child care visits are correlated with the health concern index 
at a very low level. The directions are opposite for mothers' $(r=.04)$ and fathers' $(r=-.02)$. Second, total number of vaccinations is negatively correlated with mothers' $(r=-.02)$ and fathers' $(r=-.06)$ health concern. Third, the vaccine completion scales are neither significantly correlated with mothers' $(r=.04)$ health concern nor fathers' $(r=-.05)$.

Mothers' health concern seems to be positively correlated with three measures of preventive care. On the other hand, fathers' health concern is negatively correlated with all three preventive care measures. But none of the relationships is significant. This finding is in contradiction to the hypothesis. In short, mothers' health concern seems to have positive influence on children's preventive care while fathers' health concern has negative influence.

Skepticism about Physicians

Hypothesis II states: Children's preventive care visits are negatively correlated with parents' skepticism about physicians. The findings regarding well-child care visits show opposite results for mothers and fathers. Children's well-child visits are correlated positively with mothers' skepticism $(r=.04)$, but negatively with fathers' skepticism $(r=-.08)$. The same pattern holds for the vaccine completion scale; the correlation coefficients for mothers and fathers are .05 and -.01 respectively. 
However, both mothers' and fathers' skepticism indices are positively correlated with children's total number of vaccinations $\left(r_{m}=.08, r_{f}=.05\right)$.

The findings indicate that mothers' skepticism is consistently positively correlated with three measures of preventive care. This is contradictory to the hypothesis. One interpretation could be that mothers are skeptical of physician's medical ability in general, but not the preventive care itself. Fathers' skepticism seems to be correlated, both positively and negatively, with preventive measures. However, none of these relationships is statistically significant.

Tendency to Consult Physician

Hypothesis III states: Children's preventive care visits are positively correlated with parents' tendency to consult the physician. The findings from the study are quite the opposite. Children's well-child care visits are negatively correlated with mothers' and fathers' tendency to consult the physician $\left(r_{m}=-.06, r_{f}=-.10\right)$. The same pattern seems to hold for children's total number of vaccinations, the $r^{\prime} s$ for mothers' and fathers' are -.04 and -.05 respectively. Again, children's vaccine completion scales are positively correlated with mothers' $(r=.01)$, but negatively with fathers' tendency to consult the physician $(r=-.03)$. All these findings are contrary to the hypothesis. 
$\underline{\text { Efficacy }}$

Hypothesis IV states: Children's preventive care visits are positively correlated with the degree of parents' efficacy. The only $\mathrm{HAB}$ index that is significantly associated with well-child care visits is mothers' efficacy. The correlation coefficients for mothers and fathers are .18 and .00 respectively. Neither mothers' nor fathers' efficacy is correlated with children's total numbers of vaccines $\left(r_{m}=.11, r_{f}=-.03\right)$. The vaccine completion scales are significantly associated with mothers' efficacy $(r=.18)$, but not with fathers' efficacy $(r=.02)$. The findings seem to indicate that mothers do not just bring their children in for immunization, they also select the vaccines that they think their children need.

Secondary hypothesis

As stated in chapter one, the secondary hypothesis for this study is: Mothers' health attitudes and beliefs have more influence on children's preventive care visits than fathers'. The findings in general support this hypothesis.

The $A A B$ indices that support this hypothesis are efficacy and health concern. Mothers' efficacy is significantly associated with the number of well-child care visits and the vaccine completion scale, whereas the correlation between fathers' efficacy and well-child visits 
and completion scale is very weak, with the correlation coefficients around zero. While mothers' health concern is positively associated with all three measures of preventive care, fathers' health concern is negatively correlated with preventive care measures, but neither of these relationships is statistically significant.

The findings of multiple regression on well-child visits show that more variance in well-child visits is explained by mothers' variables than fathers' (see Table $x)$. Regressions on total number of vaccinations and the vaccine completion scale show: 1) mothers' and fathers' HAB indices explain about same amount of variance (Table XXII and $\mathrm{xxxV}$, Model 1$)$; and 2) when control variables (education, age, and social class) are included in the models, a little more variance in the dependent variables is explained by fathers' variables as compared to mothers' variables (Table XXII and XXXV, Model 2). One interpretation could be that fathers' education has the strongest correlation with these two dependent variables among all the variables (Table XXIX and XXXIV).

Stepwise regression analyses on well-child visits indicate that more mothers' variables enter the regression functions than fathers' variables at the selected significant level, and more variance in well-child visits is explained by mothers' variables than by fathers' (see Table XI and XII). Similar stepwise regressions on total number of vaccinations and the vaccine completion scale 
reveal that: 1) Mothers' efficacy is the only variable entered into the equation (Table XXI and XXXVI) when only HAB indices are selected in the model; and 2) when control variables are selected into the model, more fathers' variables enter the equation than mothers', and more variance in dependent variables is explained by fathers' variables than by mothers'.

In this study, mothers' social class turns out to be consistently and significantly associated with all three measure of preventive care. Fathers' social class is negatively associated with preventive care measures at a low level (Table IX, XIX, and XXVI). In short, the findings seem to support the secondary hypothesis.

\section{LIMITATIONS OF THE STUDY}

There are several limitations in this study. First of all, the research setting for this study was kaiser Permanente Northwest Region, a prepaid group practice HMO serving mainly the Portland metropolitan area. Thus, generalization of results of the study can not go beyond the research setting. Pope found that HMO children were, consistently and across different age groups, much more highly immunized than children nationally for DPT, polio, and measles [Pope, 1980]. One factor to account for this is that, within the HMO, members get preventive care without additional charge, which includes well-child care visits and vaccinations. Thus there is much less variance 
in the dependent measures that would be found in a general population.

secondly, the HAB indices used in this study are general in nature. They are not directed at any specific preventive behaviors measured as dependent variables in the study. There is no direct measure of perceived susceptibility, perceived seriousness, perceived benefits and barriers, and cues, four key factors in HBM. Efficacy seems to be the only index that directly measures the expectancy of control in the Locus of Control Theory.

Thirdly, we should notice the high completion rates for all vaccines but mumps. (Mumps vaccine did not come into use until 1967.) They range from 66\% to $87 \%$ (Table XIII). The high completion rates imply that only small amount of variation in the data can be explained by independent variables.

\section{IMPLICATIONS OF THIS RESEARCH}

This study is not clear in showing that children's preventive care visits are associated with parents' health attitudes and beliefs. Findings of the study tend to support the Health Locus of Control Theory and the secondary hypothesis that mothers' health attitudes and beliefs have more influence on children's preventive care visits than fathers'.

Although this research is not clear in showing that HAB indices are associated with children's preventive care 
visits, coming out as a by-product, the findings do show that both mothers' and fathers' education is significantly and consistently correlated with three measures of preventive care. This finding has supported the previous studies that preventive care is highly related to education [Pope, 1978; Coburn and Pope, 1974].

Despite the limitations noted above, some findings from this study have implications for both social psychological theory and health care providers. The results suggest that the Health Locus of Control theory is useful in predicting and explaining preventive care. For health care providers, the findings suggest that mothers, traditionally acting as the gatekeepers of family health, have played a more important role in children's preventive care than fathers. In order to increase children's vaccination rates, the efforts at health education for immunization should be directed at mothers.

\section{RECOMMENDATIONS FOR FUTURE RESEARCH}

Based on the above discussion, several suggestions for future research will be pointed out. First, some more adequate measures of the four key factors in the HBM and directed at preventive care should be included in the future study. Specifically these should include the measurements of: 1) perceived susceptibility to and perceived seriousness of certain diseases; 2 ) attitudes and beliefs about immunizations and well-child care visits; and 
3) beliefs about side-effect of injections.

Second, with regard to efficacy, the measurement should focus on beliefs about efficacy regarding specific vaccines. In future research, three cognitive components of efficacy (outcome value, outcome expectancy, and efficacy expectancy) need to be treated with the same attention, since all these three factors may play an important role in one's judgment. 
REFERENCES

Ajzen, Icek \& Fishbein, Martin. 1980. Understanding Attitudes and Predicting Social Behavior. Englewood Cliffs, New Jersey: Prentice-Hall, Inc.

Anderson, Ronald. 1968. A Behavioral Model of Families' Use of Health Services. Chicago: University of Chicago Press.

Balch, P. \& Ross, A.W. 1975. Predicting success in weight reduction as a function of locus of control: A unidimentional and multidimensional approach. Journal of Consulting and Clinical Psychology (43) 119 .

Bandura, Albert. 1977. Self-efficacy: Toward a unifying theory of behavioral change. Psychological Review (84) 191-215.

Becker, Marshall H. et al. 1977. Mothers' Health Beliefs and Children's Clinic Visits: A Prospective Study. Journal of Community Health. 3(1)

Becker, Marshall H. 1974. The Health Belief Model and Personal Health Behavior. San Francisco: Society for Public Health Education.

Bem, Daryl J. 1970. Beliefs, Attitudes, and Human Affairs. Belmont, CA: Brooks/Cole Publishing Company.

Coburn, David \& Pope, Clyde. 1974 Socioeconomic status and Preventive Health Behavior. Journal of Health and Social Behavior. (15) 67-78.

Cockerham, william C. 1978. Medical Sociology. Englewood Cliffs, New Jersey: Prentice-Hall, Inc..

Colletti, G. et al. 1981. An analysis of Relapse determinants for treated smokers. Paper presented at the 89 th annual meeting of the American Psychological Association, Los Angeles.

Dabbs, J.M. \& Kirscht, J.P. 1971. "Internal control" and the taking of influenza shots. Psychological Reports (28) 959-962. 
Denton, John A. 1978. MEDICAL SOCIOLOGY. Boston, MA: Houghton Mifflin Company.

DiClemente, C.C. et al. 1985. Self-efficacy and the stages of self-change of smoking. Cognitive Therapy and Research, (9) 181-200.

Easterbrooks, Ann M. 1984. Toddler Development in the Family: Impact of Father Involvement and Parenting Characteristics. Child Development, 55 (5).

Fendrich, J.M. 1967. A study of the association among verbal attitudes, commitment, and overt behavior in different experimental situation. Social Forces, (5) $347-355$.

Festinger, Leon. 1957. A theory of Cognitive Dissonance. stanford, CA: Stanford University Press.

Fishbein, Martin \& Ajzen, Icek. 1975. Belief, Attitude, Intention, and Behavior: An Introduction to Theory and Research. Reading, Massachusetts: Addison-Wesley Publishing Company.

Gochman, DS. 1971. "Some Correlates of Children's Health Beliefs and Potential Health Behavior." Journal of Health and Social Behavior. (12) 148-154.

Gochman, David S. 1988. Health Behavior: Emerging Research Perspectives. New York, NY: Plenum Press.

Godding, P. R. \& Glasgow, R. E. Self-efficacy and outcome expectancy as predictors of controlled smoking status. Cognitive Therapy and Research, 1982 (9) 583-590.

Green, J.A. 1972. Attitudinal and situational determinants of intended behavior toward blacks. Journal of Personality and Social Psychology, (22) 13-17.

Greenlick, MR et al. (Ed.) 1988. Health Care Research in an HMO: Two Decades of Discovery. Baltimore, Maryland: The Johns Hopkins University Press.

Harris, Daniel M. \& Guten, Sharon. 1979 Health Protective Behavior: An Exploratory study. Journal of Health and Social Behavior (20) 17-29.

Heinzelmann, Fred. 1962. "Factors in Prophylaxis Behavior in Treating Rheumatic Fever: an Exploratory Study" Journal of Health and Human Behavior 73-81. 
Hibbard, Judith. et al. 1985. Age differences in Health Attitudes and beliefs: Aging and/or Cohort Effects? Int'1. Quarterly of Community Health Education. 6 (1).

Inazu, Judith K. 1980. Maternal Influence on the Sexual Behavior of Teen-Age Daughters: Direct and Indirect Sources. Journal of Family Issues. 1(1).

James, William H. et al. 1965. "Effect of Internal and External Control upon Changes in Smoking Behavior." Journal of Consulting Psychology. (2) 184-186.

Kaplan, G.D. C Cowles. A health locus of control and health value in the prediction of smoking reduction. Health Education Monographs, 1978 (6) 129-137.

Kasl, SV. et al. 1966. Health behavior, illness behavior and sick-role behavior. Arch Environ Health I 12 .

Keleges SS. 1963 Some motives for seeking preventive dental care. J Am Dental Association. (67): 90-98.

Lapiere, Richard T. 1934. Attitudes vs. actions. Social Forces, (13) 230-237.

Lau, Richard R. 1982. Origins of Health Locus of Control Beliefs. Journal of Personality and Social psychology. (42) $322-334$

Lefcourt, H.M. 1976. Locus of control: Current trends in theory and research. Hillsdale, N.J.: Erlbaum.

Leventhal, $\mathrm{H}$. et al. 1960. Epidemic impact on the general population in two cities. In the impact of Asian influenza on community life : A study in five cities. United States Department of Health, Education and Welfare, Public Health Service, Pub No 766.

Liska, Allen E. 1975. The Consistency Controversy: Readings on the Impact of Attitude on Behavior. Cambridge, Mass.: Schenkman Publishing Company.

Maiman, Lois A. et al. 1982. Effects of Sociodemographic and Attitudinal Factors on Mother-initiated Medication for Children. Public Health Reports. 97(2).

Mann, J.H. 1959. The relationship between cognitive, affective, and behavioral aspects of racial prejudice. Journal of Social Psychology, (49) 223-228.

Mechanic, David. 1968. Medical Sociology. New York, NY: The Free Press. 
Myerson, W.A. et al. Self-efficacy: The development of a brief scale for prediction of success in a smoking cessation program. Paper presented at 14 th annual convention of the Association for Advancement of Behavior Therapy, New York.

O'Leary, A. 1985. Self-efficacy and health. Behaviour Research and Therapy, (23) $437--451$.

Parsons, Talcott. 1951. The Social System. New York: Free Press.

Phares, E.J. 1976. Locus of control in personality. Morristown, N.J.: General learning Press.

Pope, Clyde R. 1976. Data from the 1970-71 Household Interview Survey. Report No. 1, Health Services Research Center, Kaiser Foundation Hospitals. Portland, oregon.

Pope, Clyde R. 1978. The Immunization Status of an HMO Population. Paper Presented at the American Pub1ic Health Association 106th Annual Meeting.

Pope, Clyde R. 1980. "The Immunization Status of Children in an HMO" Am J of Public Health (70) 3 .

Pope, Clyde R. 1982. Lifestyles, Health Status and Medical Care Utilization. Medical Care, 20.

Robinson, John \& Shaver, Phillip R. 1969. Measure of Social Psychological Attitudes. Ann Arbor, MI: Univ. of Michigan, Institute of Social Research, Survey Research Center.

Rokeach, Milton. 1970. Beliefs, Attitudes, and Values. San Francisco, CA: Jossey-Bass Inc., Publishers.

Rotter, J.B. 1966. Generalized expectancies for internal versus external control of reinforcement. Psychological Monographs, (80).

Rotter, J.B. et al. 1972. Application of a Social learning theory of personality. New York: Holt, Rinehart, \& Winston.

Rotter, J.B. 1975. Some problems and misconceptions related to the construct of internal versus external control of reinforcement. Journal of Consulting and Clinical Psychology, (43) 56-67. 
Seeman, M. \& Evans, J.W. 1962. Alienation and learning in a Hospital setting. American Sociological Review. (27).

Spears, Gregory. "Rubella cases soar across U.S.". The Oregonian October 11, 1991.

Strickland, Bonnie R. 1978. Internal-external

Expectancies and Health-related Behaviors. Journal of Consulting and Clinical Psychology, (46) 1192-1211.

Suchman, Edward. 1965. "Social Patterns of Illness and Medical Care." Journal of Health and Human Behavior. (6) 2-16.

Suchman, Edward. 1965. "Stages of Illness and Medical Care." Journal of Health and Human Behavior. (6) $114-28$.

Thomas, William I. \& Florian Znaniechi. 1918. The Polish Peasant in Europe and American. New York: Gorham.

Tolar, A. 1978. "Some antecedents and personality correlates of health locus of control." Psychological Reports. (43) 1159-65.

Twaddle, Andrew C. \& Hessleer, Richard M. 1987. A Sociology of Health. New York, NY: Macmillan Publishing Company.

Vroom, V.H. 1964. Work and Motivation. New York: Wiley.

Weinbert, Robert et al. 1984. Effects of Pre-existing and Manipulated Self-efficacy on Weight Loss in a Self-Control Program. Journal of Research in personality, (18) 352-358.

Wicker, A.W. \& R.J. Pomazal. 1971. The relationship between attitudes and behavior as a function of specificity of attitude object and presence of a significant person during assessment conditions. Representative Research in Social Psychology. (2) 26-31.

Williams, A.F. 1972. Personality characteristics associated with preventive dental health practices. Journal of American College of Dentists, (39) 225-234.

Wolinsky, Fredric D. 1988. The Sociology of Health. second Edition. Belmont, CA: Wadsworth Publishing Company.

Zimbardo, Phil et al. 1970. Influencing Attitudes and Changing Behavior. Second Edition. Reading, Mass.: Addison-Wesley Publishing Company. 


\section{AP PENDIX}

The following is the 1 ist of 14 items used to construct the Tendency to consult Physicians index.

Do you think a person should consult a doctor for headaches right away, take care of them himself, wait to see if they go away, or should he ignore them? (CONTINUE ASKING ABOUT EACH CONDITION ON THE LIST.)
A. Headaches
B. Diarrhea or constipation
C. Feeling of dizziness
D. Lump or Discolored patches on skin
E. Sore throat, runny nose
F. Backaches
G. Skin rashes
H. Shortness of breath when not exercising
I. Loss of weight without dieting
J. Feeling of tiredness
K. Sour or upset stomach
L. Common cold
M. Trouble in getting to sleep
N. Persistent cough 